University of Michigan Law School University of Michigan Law School Scholarship Repository

2012

\title{
Enforcement Without Foundation? Insider Trading and China's Administrative Law Crisis
}

Nicholas C. Howson

University of Michigan Law School, nhowson@umich.edu

Available at: https://repository.law.umich.edu/articles/707

Follow this and additional works at: https://repository.law.umich.edu/articles

Part of the Administrative Law Commons, Comparative and Foreign Law Commons, Legislation Commons, Organizations Law Commons, and the Securities Law Commons

\section{Recommended Citation}

Howson, Nicholas C. "Enforcement Without Foundation? Insider Trading and China's Administrative Law Crisis." Am. J. Comp. L. 60, no. 4 (2012): 955-1002.

This Article is brought to you for free and open access by the Faculty Scholarship at University of Michigan Law School Scholarship Repository. It has been accepted for inclusion in Articles by an authorized administrator of University of Michigan Law School Scholarship Repository. For more information, please contact mlaw.repository@umich.edu. 


\section{NICHOLAS CALCINA HOWSON*}

\section{Enforcement without Foundation?-Insider Trading and China's Administrative Law Crisis $\dagger$}

China's securities regulator enforces insider trading prohibitions pursuant to non-legal and non-regulatory internal "guidance." Reported agency decisions indicate that enforcement against insider trading is often possible only pursuant to this guidance, as the behavior identified is far outside of the scope of insider trading liability provided for in statute or regulation.

I argue that the agency guidance is itself unlawful and unenforceable, because: (i) the guidance is not the regulatory norm required by the statutory delegation of power; and (ii) the guidance is ultra vires because (a) it addresses something substantively different from what is authorized under the statutory delegation, and (b) because the guidance radically transforms the underlying basis for the breach of insider trading under Chinese law-from a modified "classical"। fiduciary duty plus misappropriation theory to an extremely robust "equal access"/mere possession of inside information theory.

I then outline potential Chinese law challenges to the norms and their enforcement, and analyze why there is such marked tolerance to plainly illegal rule-making and enforcement by what is commonly understood to be one of China's best administrative agencies.

* Professor of Law, University of Michigan Law School. In composing this Article, I have benefited from the insights of Professors Donald Clarke, Cui Wei, Keith Hand, Jamie Horsley, Huang Hui, Victoria Langland, Benjamin Liebman, Neysun Mahboubi, Curtis Milhaupt, Mathias Reimann, Shen Kui, and Alex Wang, two anonymous reviewers, and the good comments and questions received at workshop meetings convened by the Yale Law School Center for the Study of Corporate Law and the Yale Law School China Law Center in December 2011 and by the Berkeley Law School Center for Law, Business and the Economy and the Berkeley Center for Chinese Studies in February 2012. I also thank Zhang Xiaomeng of the Michigan Law School Library for her extraordinary help in tracking down electronic sources for many of the laws and regulations referred to here. All translations from Chinese into English, or vice versa, are by the author. For this Article, I have modified the standard pinyin Romanization for some Chinese terms to enhance ease of reading for those who do not know Chinese. Thus, the character sets properly rendered in pinyin Romanization as "guiding" (the verb "to regulate" or the noun "legislative provisions") and "fading" (meaning "stipulated in law") are written "gui'ding" and "fa'ding" so as to avoid conjuring the italicized English words in the phrases "the guiding light" or "the fading light."

$\dagger$ DOI http://dx.doi.org/10.5131/AJCL.2012.0011 
The infirmity underlying the basis for well-governed and investor-attracting capital markets identified here has implications not only for China's securities regulation regime and healthy market development, but also for the entirety of China's legal and administrative law system in the reform era.

\section{INTRODUCTION}

The securities regulator of the People's Republic of China (PRC) enforces statutory insider trading prohibitions pursuant to an internal norm it calls a "guidance document." Indeed, published agency decisions sanctioning private actors for insider trading demonstrate that enforcement is often possible only pursuant to this agency "guidance," because the culpable trading behavior is very different from the specific and more limited actions addressed in the operative Chinese statute. This enforcement reality is highly problematic not only because it sees a key PRC administrative agency acting far outside the scope of its legal authority, but also because the agency guidance is itself illegal and should be unenforceable.

In this Article, I argue that agency enforcement against insider trading in China is illegal for several reasons. First, the PRC's securities regulator-the China Securities Regulatory Commission (CSRC)-has not created or publicly issued a legal or regulatory norm which conforms to the statutory authorization "to regulate" or "to stipulate in regulation" (gui'ding) ${ }^{1}$ a narrow part of statutorilybased insider trading liability. Second, the non-legal, non-regulatory, guidance offered by the CSRC in response to the statutory command "to regulate" or "to stipulate in regulation" is ultra vires because: (i) it goes beyond the limited object of the relevant statutory authorization-designation of additional "persons with knowledge of inside information"; and (ii) it departs completely from the statute-based structure of China's insider trading prohibition-in U.S. jurisprudential terms, the CSRC guidance provides for a Texas Gulf Sulphur theory of liability (targeting anyone who trades while simply in possession of inside information), whereas the statute provides only for a narrow version of Cady, Roberts / Chiarella liability (applicable only to specific insiders identified in, or pursuant to, the statute) plus

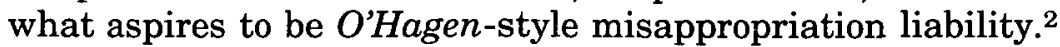

1. As Chinese readers and speakers will understand, the Chinese characters for the verbs "to regulate" or "to stipulate in regulation" (gui'ding) analyzed here are embedded in an adjectival phrase to describe "other persons." Which "other persons"? Those persons stipulated in regulation. Notwithstanding this grammatical characterization, or that the Chinese characters in question are not used in a pure verb form in the relevant statutory provision, it remains appropriate to explore the meaning and legal implications of the verb form "to regulate" or "to stipulate in regulation" (gui'ding).

2. See Part II infra for an elaborated discussion of this conflict. 
At the most immediate level, this phenomenon presents significant problems for China's securities regulator and its oversight of the PRC's dynamic capital markets. The illegality of insider trading enforcement norms casts a shadow over the ability of the PRC securities regulator to govern China's capital markets, and to thereby ensure the perceived transparency and information symmetry critical to sustaining investor confidence and participation. Any successful legal challenge to Chinese enforcement of insider trading prohibitions by defendants would constitute a body blow to this regulator's hardearned reputation for competence, regulatory power, and technical sophistication, and confirm what many small investors already understand as the unlevel playing field characterizing China's "casino" markets. Moreover, it would only contribute to a familiar vicious circle whereby the apparent ex ante costs of engaging in insider trading are virtually nil, encouraging expanded illegal activity going forward.

At a broader level, however, this seemingly technical, narrowly securities law-related, issue is but the specific identity of a much larger dysfunction that exists in many other areas of the PRC's applied legal and administrative law system. Accordingly, this problem has much wider implications for China's three decades-old "legal construction" project, the PRC's declared intention to "administer according to law" (yifa xingzheng), and what some understand as pervasive and increasing illegality across that nation's entire legal and governance system. The illegality and unenforceability of China's insider trading norms-as conceived and implemented by what many recognize as the PRC's first "modern" and most technically competent regulatory agency-and the relative tolerance shown by defendants for such illegal enforcement, provide observers with significant insights into what the Chinese contemporary legal order actually is.

The prevalence of these very issues sparked articulated central government policy and legislative concern more than a decade ago, as embodied in the 1996 PRC Law on Administrative Punishments, ${ }^{3}$ the PRC State Council's 2004 Outline for Implementing the Full Promotion of Administration According to Law, ${ }^{4}$ the 2008 State Council

3. Zhonghua Renmin Gongheguo Xingzheng Chufa Fa [PRC Law on Administrative Punishments] (promulgated by the Nat'l People's Cong., Mar. 17, 1996, effective Oct. 1, 1996), available at http://www.lawinfochina.com/Display.aspx?lib=law\&ID= 1148.

4. Guowuyuan Guanyu Yinfa Quanmian Tuijin Yifa Xingzheng Shishi Gangyao De Tongzhi [State Council Notice Regarding Printing and Distribution of the Outline for Implementing the Full Promotion of Administration According to Law] (promulgated by the St. Council, Aug. 31, 2006), available at http://www.gov.cn/ztzl/yfxz/ content_374160.htm [hereinafter, Administration According to Law Outline]. See, e.g., paragraphs 1 (exhorting "administration according to law" (yifa xingzheng) and criticizing "illegal or inappropriate administrative action"); 5(i) (urging administrative agencies to act in accordance with law, administrative regulations or departmental rules, and forbidding administrative action not stipulated in law, administrative regulations or departmental rules); 5(iii) (calling for "due process" 
Regulations on Open Government Information, ${ }^{5}$ and the very recent 2010 State Council Opinion Regarding Strengthening the Construction of Rule of Law Government. ${ }^{6}$ As the problem persists in many areas of government administration, it has also drawn the long-overdue attention of PRC legal and administrative law scholars, and even the Chinese implementing agencies concerned. ${ }^{7}$ As the PRC State Council stated very clearly in its 2010 pronouncement, ensuring that administrative rule-making and administrative law enforcement operate within the bounds described in "law" is at the very core of "rule of law government" (fazhi zhengfu) and the "rule of law" (yifa zhiguo).

This Article is organized as follows: Part I introduces the problem of insider trading, and enforcement against it, in China today, and then sets forth the formal statutory and purported regulatory bases for enforcement since the early 1990s and the establishment of China's domestic equity capital markets. Part II reveals the conflicted approach to insider trading enforcement in China as between the statutory regime, on one hand, and a 2007 norm issued internally

(chengxu zhengdang) and urging administrative agencies to "act publicly" (yingdang gongkai) in their administrative tasks); 5 (v) (stipulating that administrative agencies may only undertake enforcement within the scope authorized in law or administrative regulations); 16 (calling for greater openness in rule-making, and publication of all enforceable norms in a government gazette); 20,26, 28 and 30 (encouraging private claims for administrative rehearing or administrative litigation); 23 (limiting enforcement powers to the scope stipulated in law); 29 ((central) "filing for the record" system for departmental rules and "normative documents"), etc.

5. Zhonghua Renmin Gongheguo Zhengfu Xinxi Gongkai Tiaoli [Regulations of the PRC on Open Government Information] (promulgated by the St. Council, Apr. 5, 2007, effective May 1, 2008), art. 33(2), available at $\mathrm{http}: / / \mathrm{www}$.lawinfochina.com/Display.aspx?lib=law\&ID $=6011$, which create a presumption that government information, including rules and regulations, should be disclosed, and establishes a legal mechanism that citizens may use to compel disclosure, including administrative litigation.

6. Guowuyuan Guanyu Jiaqiang Fazhi Zhengfu Jianshe De Yijian [State Council Opinion Regarding Strengthening the Construction of Rule of Law Government] (issued by the St. Council, Nov. 8, 2010), available at http://www.gov.cn/zwgk/2010 11/08/content_1740765.htm [hereinafter, Rule of Law Government Opinion]. See, e.g., paras. 1 ("administration according to law" (yifa xingzheng) a key component of "rule of law" (yifa zhiguo), and the construction of a "rule of law government" (fazhi zhengfu); descrying mal-administration or chaotic application of administrative law and unfair application of administrative norms, or administrative agencies acting $u l$ tra vires); 6 (improve government rule-making); 7 (respect legally-stipulated constraints on power, and implement due process); 8 (review and rectify administrative regulations, departmental rules and normative documents); 9 (improve the formulation of normative documents, ensuring they are firmly based in law and do not increase civil obligations outside of those stipulated in law; normative documents not issued for comment or subject to hearings, etc., prior to enforcement are not enforceable); 10 (improve "filing and review" (bei'an shencha) system for administrative regulations and departmental rules, publicly declare invalid regulations and rules that do not conform with law); and Section VI (increase open government), etc.

7. See, e.g., Wei Cui, What is the "Law" in Chinese Tax Administration?, 19 Asia PAC. L. REV. 75 (2011) (noting the same phenomenon with respect to the issuance and application of ultra vires tax "circulars" by the PRC Ministry of Finance and the State Taxation Administration, and the latter department's July 2010 regulation designed to rationalize and legalize tax rule-making). 
by the agency charged with enforcement, on the other. In Part III, I analyze the legality and thus enforceability of that 2007 norm, and find it to be seriously deficient, making enforcement subject to legal challenge. Referring to administrative sanction decisions reported by the CSRC, Part IV reveals that the 2007 norms, which I argue are illegal and unenforceable, are very often the sole basis upon which enforcement of China's insider trading prohibitions is implemented. Part V provides a discussion of how, under Chinese law, the CSRC norms could be ruled void or unenforceable, or specific enforcement of them be overturned on appeal, with a summary outline of the possible Chinese law challenges to enforcement action (administrative and criminal) based upon such norms. In Part VI, I conclude with a broader meditation on what this problem means for China's three decades-long "legal construction" project and what it reveals about China's authentic legal, administrative law, and governance systems. Several CSRC insider trading enforcement decisions referred to in Part IV are summarized in Appendix I, and the most important statutory and non-regulatory norm provisions referred to in this study are collected in Appendix II for ease of reference.

\section{Insider Trading in China and Legal Bases for Enforcement}

\section{A. Insider Trading and Enforcement in China}

Securities fraud, including specifically insider trading, is an acknowledged fact of the Chinese domestic capital markets, and has been since the establishment of the Shanghai and Shenzhen stock exchanges in 1990-1991. Insider trading takes many forms in China. Certainly the classic situation-where corporate insiders use nonpublic material information from and regarding their company to trade in the stock of the same company prior to an announcement affecting the market price of that company's securities-is understood to occur very frequently. ${ }^{8}$

8. See, e.g., Hui Huang, The Regulation of Insider Trading in China: A Critical Review and Proposals for Reform, 17 AUSTL. J. CoRp. L. 281, 285, 286-87 (2005) (citing to Wu Hong et al., Zhongguo Zhengquan Shichang Fazhan De Falu Tiaokong [Legal Adjustments for fHe Development of China's Securities Market] 12 (2001)); Ling Huawei, Qiao Xiaohui, Fu Tao \& Hu Runfeng, Neimu Jiaoyi "Wenyi" [The Insider Trading "Plague"], CaIJING, May 28, 2007, at 66-69; Shen Han, A Comparative Study of Insider Trading Regulation Enforcement in the U.S. and China, $9 \mathrm{~J}$. Bus. \& SEc. L. 41, 56-60 (2007); Gady Epstein, Market Maker, ForbeS, Jan. 28, 2008, http://www.forbes.com/global/2008/0128/050.html; Nicholas Calcina Howson, Punishing Possession-China's All-Embracing Insider Trading Enforcement Regime, in Insider Trading Research HandBooK 2-3 (Stephen Bainbridge ed., forthcoming 2012); and the examples that are the subject of the CSRC administrative punishment decisions (xingzheng chufa juedingshu) posted continually on that agency's website, available at http://www.csrc.gov.cn/pub/zjhpublic/index.htm?channel=3300/3313 (last visited May 10,2012), including the cases analyzed in Part IV of this Article and summarized in Appendix I. 
At the same time, enforcement against insider trading in China-certainly given the amount of illegal activity commonly assumed and occasionally reported-has been anemic. ${ }^{9}$ The reasons for this are well-known and include: regulatory resource constraints (investigatory and enforcement); low levels of investigatory sophistication and deficient technical means; difficulties in detecting insider trading contemporaneously and then obtaining evidence $e x$ post $;^{10}$ the regulator's inability to act as a civil action plaintiff (and thus extract information and/or settlements from market participants); constraints on the private civil action applicable across China's corporate law and securities law regimes; the uneven competence, autonomy and independence of China's judiciary; and-of overwhelming importance in the Chinese context-the political and economic power of some of the most flagrant violators, whether individuals or institutions. Some analysts even point to a conflict in the role of China's securities regulator itself, the CSRC: tasked on one side with the protection of investors and market transparency, and on the other side ". . . provid[ing] the [state-owned enterprises] with preferential access to the financial resources of the capital market for the best interests of the government; ..."11 Whatever the constellation of reasons for it, lackluster enforcement will fuel a familiar vicious circle: obstacles to robust enforcement can ensure that the costs of insider trading are minimal or non-existent, especially when compared to the benefits on offer, which in turn only encourages further insider trading in the Chinese markets.

\section{B. Legal and Regulatory Norms}

The legal and regulatory norms governing insider trading have developed quickly in the PRC, and concurrent with-or sometimes even before-the formal, legal, establishment of China's domestic capital markets and stock exchanges. With the formation of China's

9. One author reviewing the period between 2002 and the end of 2006, or the period prior to the distribution of what this Article calls the "Insider Trading Guidance Provisions," notes the application of administrative sanctions by the CSRC in 196 cases of securities fraud, only one of which (in 2004) related to insider trading. See Han, supra note 8, at 57. See also Benjamin L. Liebman \& Curtis J. Milhaupt, Reputational Sanctions in China's Securities Market, 108 ColuM. L. REv. 929, 942 (for 2001-2006: "the number of [CSRC] sanctions seems rather modest given the ubiquity and severity of the problems with . . . insider trading . . . in China's stock markets.").

10. See, e.g., the May 2007 statement by a CSRC No. I Investigation Department official: "With respect to the investigation of insider trading, [we] face two issues: difficulties in obtaining evidence and recognition ..." Ling et al., supra note 8, at 66 .

11. Han, supra note 8 , at 58 (pointing to the "quota" system discontinued more than a decade ago, and the continued presence of poorly-performing state-owned enterprises listed on China's domestic capital markets). I do not concur with Han Shen's notion of a conflicted or even corrupt CSRC, a personal view informed by almost twenty years of interaction with the CSRC and its officers. 
first post-1949 stock exchanges in Shanghai and Shenzhen, the governments of Shanghai and Shenzhen on November 27, 1990 and May 15, 1991 respectively, ${ }^{12}$ each promulgated municipal-level "measures" (banfa) that explicitly prohibited "insider trading" (neimu jiaoyi). ${ }^{13}$ In April 1993, the State Council Securities Commission (SCSC)-the PRC State Council department governing the then newly-established CSRC ${ }^{14}$ - promulgated the first national-level regulations concerning securities issuance and trading, the 1993 Provisional Regulations on the Administration of Stock Issuance and Trading (SCSC Issuance and Trading Regulations) ${ }^{15}$ which also explicitly prohibited "insider trading." That prohibition was echoed in the September 1993 Provisional Measures on Prohibiting Securities Fraud Behavior issued by the SCSC (SCSC Securities Fraud Measures), ${ }^{16}$ which set forth the first detailed treatment of insider trading in the history of China. In October of 1997, the PRC national legislature amended the PRC Criminal $\mathrm{Law}^{17}$ to include the crime of "insider trading" (at Article 180), but without any further elaboration on the elements of this new crime (other than heightened mens reatype requirements which work across the Criminal Law).

Only in 1999, with passage of China's first post-1949 Securities Law, ${ }^{18}$ was insider trading extensively described and prohibited in a non-criminal "law" (as contrasted with an administrative regulation),

12. Shanghaishi Zhengquan Jiaoyi Guanli Banfa [Shanghai Municipal Measures on the Administration of Securities Trading] (promulgated by the Shanghai Mun. People's Gov't., Nov. 27, 1990), art. 39, available at http://vip.chinalawinfo.com/ newlaw2002/sle/slc.asp?db=lar\&gid=16778536; and Shenzhenshi Gupiao Faxing Yü Jiaoyi Guanli Zanxing Banfa [Shenzhen Municipal Interim Measures on the Administration of Stock Issuance and Trading] (approved by the People's Bank of China, Apr. 27, 1990, promulgated by the Guangdong Provincial People's Gov't., May 15, 1991, effective June 15, 1991), art. 43, available at http://www.lawinfochina.com/Display. aspx?lib=law \&ID $=591$.

13. The term "insider trading" (neimu jiaoyi) first entered China's legal and regulatory lexicon in the October 1990 Zhengquan Gongsi Guanli Zanxing Banfa [Provisional Measures on the Administration of Securities Companies] (promulgated by the People's Bank of China, Oct. 12, 1990), available at http://vip.chinalawinfo. com/newlaw2002/slc/slc.asp?db=chl\&gid=33589.

14. In April of 1998, the SCSC was disbanded, and the CSRC elevated to a regulatory department at the rank of a state ministry.

15. Gupiao Faxing Yü Jiaoyi Guanli Zanxing Tiaoli [Provisional Regulations on the Administration of Stock Issuance and Trading] (promulgated by the St. Council, Apr. 22, 1993), available at $\mathrm{http}: / / \mathrm{www} . l a w i n f o c h i n a . c o m / D i s p l a y . a s p x ? l i b=l a w \&$ ID $=1334$.

16. Jinzhi Zhengquan Qizha Xingwei Zanxing Banfa [Provisional Measures on Prohibiting Securities Fraud Behavior] (approved by the St. Council, Aug. 15, 1993, promulgated by the SCSC, Sept. 9, 1993), available at http://vip.chinalawinfo.com/ newlaw2002/slc/slc. asp?db=chl\&gid=6360.

17. Zhonghua Renmin Gongheguo Xing Fa [PRC Criminal Law] (promulgated by the Nat'l People's Cong., Mar. 14, 1997, effective Oct. 1, 1997, as amended Feb. 25, 2011), available at http://www.lawinfochina.com/Display.aspx?lib=law \&ID=354.

18. Zhonghua Renmin Gongheguo Zhengquan Fa [PRC Securities Law] (promulgated by the Nat'l People's Cong., Dec. 29, 1998, effective July 1, 1999), available at http://www.lawinfochina.com/Display.aspx?lib=law\&ID $=1084$. 
a formulation largely carried over into the extensively-revised Securities Law passed in late 2005 and effective on January 1, 2006 (2006 PRC Securities Law). ${ }^{19}$

Finally, on March 3, 2007, the CSRC conceived an internal "guidance document" (zhidaoxing wenjian) for the 2006 PRC Securities Law statutory prohibition on insider trading, the (Provisional) Guide for the Recognition and Confirmation of Insider Trading Behavior in the Securities Markets (Insider Trading Guidance Provisions). ${ }^{20}$ The Insider Trading Guidance Provisions by their own terms do not constitute publicly-issued or gazetted law or regulations, departmental rules, or any norms of which market participants have any formal notice; instead, they are self-proclaimed internal guidance for staff of the CSRC, subordinate securities regulatory bodies, and the Shanghai and Shenzhen exchanges regarding the application of law and the implementation of administrative enforcement. As this will become important for the legal analysis following, it should be emphasized that the 2007 Insider Trading Guidance Provisions are not "public" in the way that concept is understood as a legal term of art in China. While the Insider Trading Guidance Provisions appear to be "available," for instance on a widely-used subscriber on-line collection of Chinese laws and regulations, ${ }^{21}$ they are not "public" in the legal sense because they are not issued by the CSRC to the public (but instead to CSRC staff, local securities regulatory bodies, and the two Chinese exchanges), are not posted on the CSRC website, and have never been included in any form of legislative or regulatory gazette.

\section{The Chinese Insider Trading Regime(s)}

China's insider trading regulatory regime, as applied, is plagued by a very serious conflict between the system (i) as it exists in formal law, on one hand, and (ii) as articulated and increasingly enforced via agency action of dubious legality, on the other. As I demonstrate in

19. Zhonghua Renmin Gongheguo Zhengquan Fa [PRC Securities Law] (promulgated by the Nat'l People's Cong., Oct. 27, 2005, effective Jan. 1, 2006), available at http://www.lawinfochina.com/Display.aspx?lib=law \&ID $=4693$.

20. Attached to Zhongguo Zhengquan Jiandu Guanli Weiyuanhui Guanyu Yinfa "Zhengquan Shichang Caozong Xingwei Rending Zhiyin (Shixing)" Ji "Zhengquan Shichang Neimu Jiaoyi Xingwei Rending Zhiyin (Shixing)" De Tongzhi [Notice of the China Securities Regulatory Commission Regarding the Printing and Distribution of the "(Provisional) Guide for the Recognition and Confirmation of Manipulative Behavior in the Securities Markets" and the "(Provisional) Guide for the Recognition and Confirmation of Insider Trading Behavior in the Securities Markets"] (not promulgated but distributed internally by the CSRC, Mar. 27, 2007), available at http://vip. chinalawinfo.com/NewLaw2002/SLC/slc.asp?db=chl\&gid=144622 [the covering Notice hereinafter, Securities Trading Manipulation and Insider Trading Guidance Notice; the attached (Provisional) Guide for the Recognition and Confirmation of Insider Trading Behavior in the Securities Markets hereinafter, the Insider Trading Guidance Provisions].

21. E.g., ChinaLawInfo (http://www.chinalawinfo.com). 
this Article, the latter non-law-based structure cuts the insider trading breach out of a whole new cloth and authorizes enforcement of insider trading liability against mere possessors of non-public, material, information who happen to trade securities during a subsequently-determined price sensitive period.

Before I analyze and explain the very serious dysfunction between the statutory or "legal" regime, on one side, and the administrative enforcement structure, on another, it may be helpful to keep in mind two trading situations where insider trading liability might be at issue, depending upon how an insider trading regime is crafted: (i) "tippee" trading, and (ii) where an individual who acts as the financial advisor to an acquiring company trades in the stock of a listed target-defined here in short form as "tippees" and "M\&A advisors" respectively. As will be shown below, in each case (and other than tippees or M\&A advisors who misappropriate inside information), there is no basis for the assertion of insider trading liability against such persons trading on non-public, material, information under the 2006 PRC Securities Law. The only basis for enforcement or prosecution against such persons lies in what I argue are the legally defective 2007 Insider Trading Guidance Provisions. ${ }^{22}$

\section{A. The 2006 Statutory Scheme}

The 2006 PRC Securities Law addresses insider trading in eight articles of the statute. ${ }^{23}$ Most fundamentally, Article 73 states:

Article 73. It is prohibited for those with knowledge of securities trading [related] inside information or those who have illegally procured inside information to use inside information in undertaking securities trading activities.

This key article prohibits (i) those "with knowledge of securities trading [related] inside information" and (ii) those "who have illegally procured inside information," from using inside information to engage in securities trading activities. For ease of reference, I will refer to these two distinct bases for insider trading liability as "PWKII" (for persons with knowledge of securities trading related inside information) and "misappropriation" respectively.

22. See, e.g., infra Part IV, and Appendix I (in particular, the Jia Huazhang \& Liu Rong Decision (tippee liability) and the Zhang Xiaojian Decision (M\&A advisor liability)).

23. See 2006 PRC Securities Law, supra note 19, arts. 5 (basic prohibition against insider trading), 47 (short-swing trading by insiders), 73-76 (elaborated provisions on insider trading, analyzed here), 180 (power of the CSRC to stop trading in suspect securities), and 202 (administrative penalties and measures). Criminal prosecution for the established crime of insider trading (at Article 180 of the PRC Criminal Law) is explicitly authorized at Article 231, while civil damages (and, perhaps, a private claim in damages) are given a legal basis in the final clause of Article 76. 


\section{1. "Persons with Knowledge of Inside Information" (PWKII)}

The 2006 statute (like its 1999 predecessor) in Article 74 explicitly narrows the scope of possible defendants who may be deemed PWKII:

Article 74. Persons with knowledge of securities trading [related] inside information include: . . .

Those designated "include" (baokuo): a roster of traditional issuer, market or regulatory insiders (via Article 74(i)-(vi)), ${ }^{24}$ and "other persons stipulated in regulation (gui'ding) by the State Council Securities Regulatory Organ [i.e., the CSRC]" (via Article 74(vii)).

It is unclear whether the Chinese form of "including" (baokuo) here means "including only" or "including without limitation." We do know, however, that Chinese legislative drafting practice, certainly for statutes drafted at the time of the 2006 PRC Securities Law, which seeks to codify the understanding "including without limitation" increasingly uses the characters "baokuo dan buxianyu," a form not employed in this instance. Accordingly, this Article 74 iteration of "include" (baokuo) must be taken as a very strong indication that persons not included in the statutory enumeration, or not specifically designated by the CSRC pursuant to Article 74(vii), cannot be insider trading defendants for the PWKII prong of liability.

The specific delegation of regulatory authority to the CSRC to designate other PWKII is drafted with some art:

Article 74. . . . (vii) other persons stipulated in regulation (gui'ding) by the State Council Securities Regulatory Organ.

This should be distinguished from a similar grant of authority, again to the CSRC, to merely "recognize and confirm" (ren'ding) other information that might constitute inside information in nearby Article 75(viii) of the 2006 PRC Securities Law.

24. These statutory PWKII are: directors, supervisory board members, and senior managers of the issuer; five percent or more shareholders of the company and its/their directors, supervisory board members and senior managers, and the actual controlling shareholders of the company and its/their directors, supervisory board members and senior managers; directors, supervisory board members and senior managers of companies controlled by the issuer; people whose executive or staff position in the company provides access to inside information; CSRC staff and others who pursuant to their legally stipulated duties administer or regulate securities issuance and trading; and relevant securities sponsors, underwriters, securities exchange personnel, securities registration and settlement personnel, and securities service institution personnel. (The CSRC must have seen how badly drafted the statutory provision in italics above was, and so very appropriately sought to adjust it in the 2007 Insider Trading Guidance Provisions to cover: "the controlling shareholders of the issuer or listed company, other companies controlled by the actual control party, and their directors, supervisory board members and senior management." See Insider Trading Guidance Provisions, supra note 20, art. 6(2)(ii).) 
Article 74(vii) of the 2006 PRC Securities Law allows the CSRC to identify - by the act of "regulating" or "stipulating in regulation" (gui'ding)-“others" (qitaren), aside from the traditional insiders enumerated in Article 74(i)-(vi), as PWKII. ${ }^{25}$ Given the predominant and continuing Chinese focus on statutorily-enumerated insiders, this grant of regulatory authority to the CSRC in Article 74(vii) to widen the scope of PWKII represented in 2006 a significant nod in the (future) direction of loosening the perhaps under-inclusive list of PWKII-related insider trading defendants. ${ }^{26}$

In sum, the effect of Articles 73 and 74 of the 2006 PRC Securities Law is to limit the scope of PWKII insider trading defendants to those persons or institutions enumerated in Article 74(i)-(vi), or additional persons formally designated ex ante in CSRC regulation pursuant to Article 74(vii). ${ }^{27}$ For scholars familiar with U.S. insider trading jurisprudence, this statutory regime seemingly rejects the SEC v. Texas Gulf Sulphur ${ }^{28}$ "equal access theory" expansion of Cady, Roberts \& Co., ${ }^{29}$ which extended insider trading liability from "corporate insiders" to anyone in possession of material, non-public information. Instead, the PRC regime tracks the narrowing of insider trading liability also seen in the United States to something closer to the "classical" or fiduciary duty theory in Chiarella $v$. United States, ${ }^{30}$ so that insider trading liability is limited to those in breach of some kind of fiduciary or special relationship of trust and confidence with the trading counterparty. ${ }^{31}$

\section{A "Misappropriation" Basis}

In addition to the PWKII basis for insider trading described immediately above is the insider trading liability created by the second prong of Article 73 read in conjunction with a phrase in Article 76 of the 2006 PRC Securities Law, which provides for a separate "misappropriation" theory of insider trading for China. These provisions of

25. There was no need to grant the CSRC authority to widen the scope of defendants independently subject to the misappropriation prong because there is no defined class of "persons who have illegally procured inside information" as there is for "persons with knowledge of inside information."

26. As is consistent with larger patterns in PRC legislative practice, designed to allow a certain level of generality in law, while conferring significant discretion on administrative institutions.

27. As is consistent with the earliest iterations of insider trading law in China, which addressed only the actions of formal (status) insiders. See, e.g., SCSC Issuance and Trading Regulations, supra note 15, art. 81, and SCSC Securities Fraud Measures, supra note 16 , art. 5.

28. SEC v. Texas Gulf Sulphur, 401 F.2d 833 (2d Cir. 1968), cert. denied 394 U.S. 976 (1969).

29. Cady, Roberts \& Co., 40 S.E.C. 907 (1961).

30. Chiarella v. United States, 445 U.S. 222 (1980).

31 . With the exception of the tender offer context, where the "equal access" theory lives on in the U.S. Securities and Exchange Commission's 1934 Securities and Exchange Act Rule 14e-3, see 17 C.F.R. \& 240.14e-3 (1981). 
the 2006 PRC Securities Law establish the culpability of anybody who has "illegally procured inside information" (feifa huoqu neimu xinxi de ren). Persons who misappropriate inside information are identified separately from, and do not have to be in the class of, the enumerated PWKII set forth in Article 74.

Again in U.S. jurisprudential terms, this formulation is meant to track the relatively recent (1997) innovation in United States $v$. O'Hagen,$^{32}$ which created an expanded basis of insider trading liability for traders who breach a fiduciary duty or other special relationship with the source of the inside information-recall that per Chiarella the special duty or relationship must be with the trading counterparty.

For those who misappropriate inside information, therefore, to effect a successful enforcement action the PRC government only needs to demonstrate: (i) "illegal procurement" of information, (ii) that such information is "inside information," (iii) use of that inside information to trade, and (iv) trading of securities (of an issuer related in some way to the information). For this prong, there is no need to establish that the trader is a PWKII.

\section{3. "Use" of Inside Information and a Legal Basis for "Tipper" Liability}

In defining what exactly the prohibited "use" (liyong) of inside information is, the 2006 PRC Securities Law elaborates on the legal duties of both PWKII and those who have misappropriated, duties which again seem to track, in part, the U.S.-style, "disclose or abstain from trading" rule: people in possession of "inside information [relevant to specificl securities trading" (zhengquan jiaoyi neimu xinxi) are prohibited from (i) purchasing or selling that company's securities, (ii) disclosing such information, or (iii) suggesting that others purchase or sell such securities, in each case at any time before such inside information is publicly disclosed (gongkai). ${ }^{33}$

The third prong in the summary immediately above-"suggesting that others, etc ..."-is the basis in Chinese law for yet another kind of insider trading liability, what other jurisdictions call "tipper" or "tipping" liability, or what the statutory provision describes as "suggesting that others purchase or sell such securities." Note than an individual can be liable for insider trading under this basis even where the defendant has not actually engaged in securities trading (but most assuredly "used" inside information by suggesting that another person trade on it).

32. United States v. O'Hagen, 521 U.S. 642 (1997).

33. 2006 PRC Securities Law, supra note 19, art. 76. 
Conversely, "tip" recipients-or "tippees"-are not subject to insider trading liability under the 2006 PRC Securities Law formulations, at least insofar as they are not PWKII enumerated in Article 74(i)-(vi), identified in any publicly issued CSRC regulation as PWKII pursuant to Article 74(vii), or deemed to be guilty of misappropriation of the information under the second prong of Article 73 and Article 76.

\section{No Breach of Duty or Scienter Requirement}

On first blush, the statutory scheme outlined above may seem overbroad with respect to liability for innocent traders who happen to be a part of the enumerated class of PWKII. This concern will be rooted in the fact that, at least in the civil and administrative enforcement sphere, there is no proxy for a requirement of scienter or breach of duty by the defendants with respect to their illicit use of valuable information or any duty they owe to others. This in turn raises the very strong possibility of something like strict liability for certain individuals who trade innocently in the relevant securities while they happen to be in possession of inside information. ${ }^{34}$

There is in fact no great need for a proxy for the requirement of scienter or breach of duty by the defendants under either statutory prong of the insider trading breach, PWKII or misappropriation. For the PWKII basis, the strict delimitation of persons included within the scope of PWKII under the statute or any qualifying public regulation ensures that persons captured by the statutory formulation "should have known" that information in their possession is non-public, may be valuable, and that they should not trade on it. For the misappropriation basis, confirmed "illegal procurement of inside information" serves fairly well as an indication of some kind of guilty intent or breach of a legal or ethical duty to the source of the information. There is even less need for any proxy for breach of duty or scienter in respect of the crime of "insider trading" under Article 180

34. Which has pushed good faith efforts by authoritative scholars of Chinese law to divine something less draconian than strict liability. See, e.g., Huang, supra note 8 , at 291-92, 294-95 (citing to the 1999 PRC Securities Law equivalent of Article 74 of the 2006 PRC Securities Law, and referring to two tests "for proving the defendant's knowledge that the information is inside information, namely the subjective knowledge test to prove the insider 'knew' and the objective knowledge test to prove that the insider 'ought to have reasonably known' ...", as well as ". . . an additional 'personal connection" "test to define insiders, requiring that there must be a causal link between the insider's position and the acquisition of information ..." such that trading is only prohibited if PWKII "have access to the information by virtue of their connection with the company whose securities are affected, by virtue of their office or profession"). 
of the PRC Criminal Law, because all crimes require some showing of intentionality (interpreted as actual intent or recklessness). ${ }^{35}$

Importantly for this analysis, however, the lack of need for a scienter or breach of duty requirement under the statute for civil enforcement is only valid if the insider trading breach is constructed in the limited way set forth under the 2006 PRC Securities Law. If that limited architecture is widened or dismantled-as I demonstrate it is under the CSRC's 2007 Insider Trading Guidance Provisions analyzed here-then this failure to require breach of duty or scienter will constitute a critical defect. ${ }^{36}$

\section{No Insider Trading Liability for: Tippers Who are Not PWKII; Tippees; and M\&A Advisors}

From the foregoing analysis it should be clear that the statutory structure for the assertion of insider trading liability under Chinese law is in fact under-inclusive. For instance, individuals who are not part of the Article 74-enumerated class of PWKII and who trade on statutorily-defined inside information, even tippers alluded to in Article 76 who are not PWKII (and have not engaged in misappropriation), cannot be liable for insider trading. Likewise, neither tippee traders nor M\&A advisors defined above ${ }^{37}$ who are not part of the Article 74-enumerated class of PWKII would have exposure to insider trading liability (again, unless independently guilty of misappropriation). Why is this true? Tippees are exculpated because Article 76 only prohibits tipping (although "tippees" would have liability if members of the Article 74-enumerated class, or their receiving the tip constitutes "illegal procurement" of inside information). M\&A advisors-again, if not guilty of misappropriation of inside information - are also outside of the enumerated class of PWKII listed in Article 74, as they are not employed at the company which issues the securities traded with the benefit of inside information.

These several examples of behaviors that are not captured by the statutory prohibition against insider trading are to be kept in mind, because in Part II.B.2 below I show how the same behaviors are covered by the new architecture and expanded substantive scope of the CSRC's 2007 Insider Trading Guidance Provisions.

35. PRC Criminal Law, supra note 17, art. 14. Merely negligent behavior is only subject to criminal prosecution when the PRC Criminal Law explicitly says so. Id. art. 15.

36. See infra Part II.B.1.

37. See supra note 22 , and text. 


\section{B. Agency Designation of "Insiders" and a Parallel (and Conflicting) Enforcement Regime}

As noted above, the CSRC evidently created the 2007 Insider Trading Guidance Provisions in response to the invitation in Article 74(vii) of the 2006 PRC Securities Law. I argue here that the job was botched very badly, with the CSRC making non-public, non-regulatory, norms of doubtful legality that nonetheless far exceed the statutory rule-making invitation. The Insider Trading Guidance Provisions do widen very significantly the defined scope of PWKII under Article 74, but then go many steps further to actually recast insider trading in toto and create new and additional bases for insider trading liability in China, far beyond that ever contemplated in China's 2006 Securities Law. The result, in U.S. jurisprudential terms, is non-public "guidance" - not law or administrative regulation-of very uncertain enforceability that makes for an extremely robust Texas Gulf Sulphur-type "equal access" theory of liability capturing just about anyone trading while in possession of material, non-public, information.

\section{Insider Trading Radically Reconfigured}

How do the CSRC's Insider Trading Guidance Provisions accomplish this wholesale restructuring of PRC insider trading law? Article 12 of the Insider Trading Guidance Provisions (under a Section IV entitled "The Recognition and Confirmation (ren'ding) of Insider Trading Behavior") ignores entirely the statutory scheme of the 2006 PRC Securities Law and sets forth a brand new architecture establishing the elements of insider trading, as follows (with new or newlydefined terms italicized):

Article 12. Securities trading activity that conforms to the following conditions shall constitute insider trading: (1) the person undertaking the behavior is an insider; (2) the information involved is inside information; and (3) the subject person buys or sells related securities during the price sensitive period of the inside information, or suggests that other persons buy or sell related securities, or [publicly] reveals the [inside] information. ${ }^{38}$

This formulation is at substantial variance with, and goes far beyond, the insider trading regime as it is defined in Articles 73-76 of the 2006 PRC Securities Law described above. Most critically, Article 12 of the Insider Trading Guidance Provisions creates a new defined

38. Each of "insider," "inside information," and "price sensitive period" are defined under the 2007 Insider Trading Guidance Provisions, only one of which ("inside information") is defined under the statute. The expanded definition of PWKII is folded into the new defined term "insider." 
term-"insider" (neimuren) -which term does not appear in the 2006 PRC Securities Law. ${ }^{39}$ The 2006 PRC Securities Law never addresses the liability of "insiders." Instead, it only speaks to the culpability of three actors: PWKII, those who have misappropriated inside information, and either of the foregoing who are also tippers of inside information.

The Insider Trading Guidance Provisions, only permitted by Article 74(vii) of the 2006 PRC Securities Law to elaborate in regulation additional members of the class of persons included in the statutory category of PWKII, do exactly the opposite: they absorb the 2006 PRC Securities Law Article 74(i)-(vi) statutory list of PWKII into the Guidance Provisions-created category of "insiders." That statutorilyungrounded definition of "insider" is then further expanded in the Insider Trading Guidance Provisions ${ }^{40}$ to include:

- The securities issuer, or listed company (as PWKII)

- The controlling shareholder of the issuer or listed company, companies controlled by the actual control party of the issuer or listed company, and their respective directors, supervisory board members and senior management (as PWKII)

- Any party involved in a listed company's merger, acquisition or reorganization and their relevant personnel (as PWKII)

- Persons who gain inside information in the performance of their work (as PWKII)

- The partners and spouses of those natural persons included in Article 74(i)-(vi) of the 2006 PRC Securities Law (i.e., statutorily-defined PWKII)

- The parents or children or other relatives of any natural persons included in the above categories who come into possession of inside information

- Those who employ illegal methods such as trickery, coaxing, eavesdropping, monitoring, secret trading, etc. to gain inside information.

- Those who gain inside information through other channels.

Another part of the Insider Trading Guidance Provisions stipulates that such "insiders" may be legal persons (corporate entities) as well as natural persons. ${ }^{41}$

Perhaps most egregiously expansive in the non-statutory, nonregulatory formulation of "insider" is the last bullet above, which makes an "insider" anyone "who gains inside information through other channels." This is tantamount to declaring that trading while

39. Insider Trading Guidance Provisions, supra note 20, arts. 5 and 6.

40. Id. arts. 6(2)-(5).

41. Id. art. 5 . 
simply in possession of inside information (and during a price sensitive period) is a basis for insider trading liability in the PRC.

There is much else besides in the 2007 Guidance Provisions that is new, and not based in, or directly contrary to, the statute. ${ }^{42}$ The foregoing simple recitation of the Guidance Provisions' Article 12 architecture and the Chinese law neologism of "insiders" should suffice to make clear that the CSRC internal guidance explodes the bounds of the 2006 PRC Securities Law. Whereas under the 2006 Securities Law only a narrowly-defined class of PWKII or those engaged in misappropriation of inside information (acting directly or as tippers) could be liable for specifically-defined illegal behavior, under the 2007 CSRC Guidance Provisions any person simply in possession of information (and thus an "insider" under the 2007 Provisions) which is determined to be "inside information" who "purchases or sells relevant securities, or suggests that another purchase or sell such securities, or communicates such inside information" during a "price sensitive period" 43 will be liable for insider trading. ${ }^{44}$ The result is strict liability under the Insider Trading Guidance Provisions for anyone trading in securities, or simply tipping, when deemed to be in possession of inside information and during a price sensitive period.

In fairness, the liability conjured is not absolutely strict as the same 2007 Guidance Provisions introduce a scienter-like requirement, something which I argue above is not necessary for the narrower statutory regime focusing on status insiders and those who misappropriate. ${ }^{45}$ The Guidance Provisions require a determination as to "whether or not [the defendant] knew or was informed of (zhicai) inside information"-but it does so only for (i) "the parents or children or other relatives of any natural persons" included in the expanded scope of PWKII in the 2007 Guidance Provisions, ${ }^{46}$ and (ii) "those who employ illegal methods such as trickery, coaxing, eavesdropping, monitoring, secret trading, etc. to gain inside information;" and "those who gain inside information through other channels." 47

42. See Howson, supra note 8, at 23-25 (describing the altered definition of inside information and the new concept of the "price sensitive period").

43. The "price sensitive period" is also a new concept introduced by the 2007 Insider Trading Guidance Provisions which makes only less certain when information is no longer "material" or "inside information."

44. It should be noted that the Insider Trading Guidance Provisions, at Article 19, provide diverse bases for exculpation, ranging from blanket exceptions (e.g., stock buy-backs or transactions pursuant to triggered mandatory offers) to knowledge defenses, and even the broad discretion of the CSRC.

45. See supra notes 34-36, and text.

46. Who are: the securities issuer, or listed company; the controlling shareholder of the issuer or listed company, companies controlled by the actual control party of the issuer or listed company, and their respective directors, supervisory board members and senior management; any party involved in a listed company's merger, acquisition or reorganization and their relevant personnel; and persons who gain inside information in the performance of their work.

47. Insider Trading Guidance Provisions, supra note 20, art. 14(2). 
This will be cold comfort for the huge class of other potential defendants, for at the same time the 2007 Guidance Provisions make insider trading liability only stricter for (i) the PWKII originally listed in the 2006 Securities Law at Article 74(i)-(vi) and (ii) the expanded scope of such persons absorbed into PWKII from the Guidance Provisions. This reverses the burden of proof for all such defendants so that they will be liable for insider trading during the price sensitive period unless "they have sufficient evidence to demonstrate that they did not know or were not informed of inside information."48

To be absolutely clear, the issue specifically addressed here is not that the CSRC has broadened the scope of PWKII, something that the agency was perfectly entitled to do in conformity with the PRC legal and administrative law system. Instead, the problem is that the CSRC has created a whole new class of defendants outside of the only actors addressed in the Securities Law-PWKII and those who misappropriate (acting directly or as tippers)—called "insiders," who can now be exposed to serious liability if they trade during a price sensitive period with respect to any securities (i.e., not the securities of the company relevant to their status), and with a new burden of proof which almost assures their guilt-unless they can prove a negative: that they did not know or were not informed of the inside information.

2. Newly-created, "Guidance"-based, Insider Trading Liability for: "Tippers" Who are Not PWKIIs; "Tippees"; and M\&A Advisors

In Part II.A.5, I have shown how none of the following constitutes behavior that is culpable under the 2006 PRC Securities Law: (i) tipping by persons not PWKIIs or misappropriaters, (ii) tippee trading, and (iii) M\&A advisor trading.

Yet all of these same behaviors are culpable under the vastly expanded reach of the 2007 CSRC Insider Trading Guidance Provisions. Thus, tippers who have not misappropriated inside information and who are not within the statute's enumerated class of PWKIIs would still be liable for insider trading if they purchase or sell securities during the price sensitive period. Similarly, tippee traders who have not engaged in misappropriation of inside information but who trade during the price sensitive period would be liable for insider trading. M\&A advisors consulting for an acquirer and trading in the shares of a target company during a price sensitive period would also be liable for insider trading. In each case, there is newly-crafted insider trading liability for securities traders under the

48. Id. art. 14(1). 
CSRC Insider Trading Guidance Provisions, liability for which there is no basis whatsoever in the 2006 PRC Securities Law.

As discussed in more detail below, the problem identified only becomes worse when we confront the fact that the CSRC (and likely the People's Procuratorate in the criminal sphere) is actually enforcing China's insider trading prohibitions in precisely this way, and therefore without any grounding in the nation's 2006 Securities Law or any other "legal" norm.

III. Legal and Regulatory INFIrmity of the Insider Trading Guidance Provisions

The CSRC 2007 Insider Trading Guidance Provisions are illegal and should be unenforceable, for two reasons:

First, the CSRC has not actually promulgated legislative provisions, administrative regulations, departmental rules, administrative measures ${ }^{49}$ or indeed any species of public rule-making under the authority granted to it in Article 74(vii) of the 2006 PRC Securities Law with the characters "gui'ding," translated here as "to regulate" or "to stipulate in regulation." Instead, in 2007 the CSRC only distributed, internally and not publicly, the Insider Trading Guidance Provisions which are mere "guidance" (zhiyin) or a so-called "guidance document" (zhidaoxing wenjian) and which declare, by their own terms, that they function to "recognize and confirm" (ren'ding)—not "stipulate in regulation" (gui'ding) - the enforcement of legal norms for insider trading.

Second, the 2007 Insider Trading Guidance Provisions are ultra vires because (i) the Guidance Provisions address far more than simply "other" PWKII, the limited object of the 2006 PRC Securities Law Article 74(vii) statutory authorization; and (ii) the insider trading breach described in the totality of the Insider Trading Guidance Provisions departs completely from, and vastly expands, the insider trading prohibition set forth in the 2006 PRC Securities Law.

\section{A. Regulatory and Administrative Law Infirmity}

1. The Verb "to Regulate" or "to Stipulate in Regulation" (gui'ding) as used in the 2006 PRC Securities Law

If my argument that the 2007 CSRC Insider Trading Guidance Provisions do not conform to the statutory command of the 2006 PRC Securities Law is to be deemed valid, a first critical question is the precise meaning of the authorization for the CSRC "to regulate" or "to stipulate in regulation" (gui'ding) additional PWKII under Article 74(vii) of the 2006 PRC Securities Law-especially when contrasted

49. All English language translations of Chinese language terms of art. See infra notes 53-66, and text. 
with the adjacent Article 75(viii) allowance for the CSRC to merely "recognize and confirm" (ren'ding) important information having a significant effect on securities prices as part of the definition of "inside information."

Inside the four corners of the 2006 PRC Securities Law, there is a hierarchy of contemplated regulatory actions, by the CSRC and other departments, as follows: ${ }^{50}$

- recognize and confirm (ren'ding)

- formulate (zhiding)

- regulate, or stipulate in regulation (gui'ding)

- stipulate in law (fa'ding).

Below I address this hierarchy slightly out of order, to situate the meaning of the verb command "to regulate" or "to stipulate in regulation" (gui'ding) as it appears in Article 74(vii) of the 2006 PRC Securities Law, and to determine what kind of resultant administrative law action is required and sufficient for the verb command.

\section{a. "Recognize and Confirm"; "Formulate"; and "Stipulate in Law"}

The Chinese characters for the verb form "to recognize and confirm" (ren'ding) appear only a few times in the 2006 PRC Securities Law outside of the Article 75(viii) provision allowing definition of important information having a significant effect on securities prices. Article 2 uses that character set in referring to other instruments "recognized and confirmed" by the State Council (and not the CSRC) "in accordance with law" (yifa) as securities covered by the Securities Law. Likewise, Article 170 provides that standards and administrative measures for the qualification of securities industry service firms are to be "recognized and confirmed." It is not clear from the face of the 2006 PRC Securities Law if the act of "recognizing and confirming" places a lesser burden on the regulator and the nature of the resulting authorized regulation as compared with "regulate" or "stipulate in regulation" (gui'ding) and "stipulate in law" (fa'ding) analyzed below; indeed, the modifying phrase "in accordance with law" (yifa) in Article 2 might indicate just the opposite, and that the regulator's burden of "recognizing and confirming" is equivalent to that of "regulating" or "stipulating in regulation" (gui'ding). Nonetheless, the lack of the Chinese character "gui" in the compound for "recognize and confirm" (ren'ding), strongly indicates for Chinese readers something less than stipulation in formal regulation or law.

50. The CSRC is permitted many other actions in the 2006 PRC Securities Law, including "rendering administrative punishments," "making decisions," "approving," "designating," "making orders," etc. However, only the verb forms which implicate some kind of enforceable norm-making activity are analyzed here. 
In addition, the CSRC is tasked with "formulating" (zhiding) different norms at five places in the 2006 PRC Securities Law. At Article 149, the character set is used to describe what the CSRC will do with respect to "specific measures" (juti banfa) for instruction of audit or asset appraisal of securities companies. Article 169 instructs the CSRC to formulate "administrative measures" (guanli banfa) for the examination and approval of securities industry service firms. Article 170 calls for CSRC formulation of the "recognition and confirmation" (ren'ding) of "qualification standards" and "administrative measures" (guanli banfa) for securities industry service firms. Finally, Articles 179(i), 179(iv) and 184 allude to instances where the CSRC generally will formulate: "departmental rules" and "rules" (guizhang, guize) for supervision of the securities markets; qualification standards and practice standards for securities professionals; and "departmental rules" and "rules" (guizhang, guize)-in each case "in accordance with law." 51 While Chinese readers will recognize the verb "to formulate" (zhiding) as a looser way of saying "to stipulate," it is noteworthy that in each case this verb form is associated with a norm-product that includes "departmental rules" or "rules" (guizhang, guize), public standards or qualifications, and "measures" (banfa) (a type of enactment with a specific meaning in the Chinese administrative law scheme). ${ }^{52}$

The only character set apparently more onerous than "regulate" or "stipulate in regulation" (gui"ding) appearing in the 2006 PRC Securities Law is the verb form that should be translated as "stipulated in law" ( $a^{\prime}$ 'ding). This formulation appears in Article 57 (issuers must conform to conditions for debt issuances stipulated in law), Article 74 (people engaged in administration of securities issuance, or trading), and Article 128 (conditions and procedures for review of securities firm establishments). In addition, Article 139 has the single instance of the phrase that " $f a$ 'ding" is a contraction of, "falü gui'ding de," also meaning "as stipulated in law" (alluding to other situations regarding the handling of customer securities accounts). This character grouping sets the highest bar, mandating stipulations contained in law and not a lesser form of legal or regulatory enactment.

\section{b. "To Regulate" or "To Stipulate in Regulation"}

The Chinese characters "gui'ding"- used as a verb or embedded in an adjectival phrase-appear in at least forty-five articles in the

51. The same verb "to formulate" (zhiding) is also used in connection with the stock exchanges' obligation to formulate articles of association, listing rules, trading and settlement rules, trading powers of attorney, and the settlement and clearing institution's obligation to formulate business rules.

52. See infra note 57 , and text. 
2006 PRC Securities Law. ${ }^{53}$ A single provision of the statute sets forth a slight variation on the verb form, instructing the CSRC to "make regulation" (zuochu gui'ding) regarding the business activities and certain financial ratios applicable to securities firms. ${ }^{54}$

The scope of norm-vehicles or anticipated products for the verb action to "regulate" or "stipulate in regulation" (gui'ding) is limited, and includes only: (i) the Securities Law itself (ben fa) or another statute ( $f a$ ) like the 2006 PRC Company Law; (ii) law (falï); (iii) legislative provisions (gui'ding, as a noun), a term of art translation that includes law, administrative regulations and departmental rules; (iv) laws and administrative regulations (falü xingzheng fagui and falü xingzheng gui'ding); and (v) administrative measures (guanli banfa) or specific (administrative) measures (juti banfa). ${ }^{55}$ Other than in three unrelated articles which address rule-making by China's stock exchanges, ${ }^{56}$ never in the 2006 PRC Securities Law is there an association between the act "to regulate" or "to stipulate in regulation" (gui'ding), on one hand, and resulting identified legal or regulatory norms, on the other, via anything other than specific statute, laws, legislative provisions, laws and administrative regulations, administrative measures or specific (administrative) measures. Indeed, the CSRC is never permitted in the statute to "regulate" or "stipulate in regulation" (gui'ding) departmental rules (guizhang) or rules (guize), which are the exclusive product of the verb form "to formulate" (zhiding).

53. See, e.g., 2006 PRC Securities Law, supra note 19, arts. 2 (items stipulated in other "laws and administrative regulations" (falü xingzheng fagui), the State Council to stipulate "administrative measures" (xingzheng banfa)); 10 (conformity with conditions stipulated in "laws, administrative laws and regulations"); 11 (other securities stipulated in "laws, administrative laws and regulations," stipulated qualifications and administrative measures for sponsors); 66 (other matters to be included in "Major Events" periodic reporting); 71 (mandatory public disclosure); 87 (reports and announcements stipulated in the 2006 PRC Securities Law itself); 101 (specific measures for the takeover of listed companies); 124 (requirements for establishment of securities firms); 133 (persons prohibited from senior posts at securities firms); 162 (settlement risk fund measures and funding); 179 (other powers for the CSRC); 229 (listing conditions); and 239 (specific measures for purchase and trading of domestic securities in foreign exchange), etc.

54. Id. art. 130.

55. See, e.g., id. arts. $2,5,6,10,11,24,49,71,87,90,101,108,116,123,133,139$, $156,163,172,179,208,229$, and 239 .

56. See id. arts. 52(viii), 55(v), and 58(vii) which reference-exclusively-stock exchange listing rules (shangshi guize) or just exchange rules (jiaoyisuo guize) as the result of the verb action "to regulate" or "to stipulate" (gui'ding). The characters "gu$i z e$ " which can be translated as "rules," and which are referenced several times in the statute independently of the act of regulation or stipulation in regulation (gui'ding), seem associated in the Chinese discourse with rules issued by self-regulating bodies or associations, and something less than legal (and perhaps regulatory) norms, including "departmental rules." See also id. art. 179, where the CSRC is obligated to "formulate (zhiding) securities market administration rules (guizhang, guize) in accordance with law..." 
c. The Meaning of the Verb Form "To Regulate" or "To Stipulate in Regulation" (gui'ding) under Article 74(vii) of the 2006 PRC Securities Law

Said another way, the uniform internal architecture of the 2006 PRC Securities Law indicates that the statutory authorization directing the CSRC "to regulate" or "to stipulate in regulation" (gui'ding) in Article 74(vii) can only be implemented by something which constitutes laws, legislative provisions, laws and administrative regulations, administrative measures or specific (administrative) measures. ${ }^{57}$ Even where the less onerous verb form "to formulate" (zhiding) is used at Articles 179(i), 179(iv) and 184, the CSRC is explicitly charged with formulating norms subordinate to laws, legislative provisions, laws and administrative regulations, administrative measures or specific (administrative) measures"departmental rules" and "rules" (guizhang, guize) and public standards or qualifications_-"publicly" and "in accordance with law."

\section{The 2006 PRC Securities Law Requirement that the CSRC Act "Publicly"}

Finally with regard to the internal mandates of the 2006 PRC Securities Law itself, Article 184 states very clearly that "[the CSRC] in formulating departmental rules and rules (guizhang, guize) and its supervisory administration work system shall [do so] publicly (yingdang gongkai)." 58 This constitutes a clear legal requirement that regulatory and enforcement norms and action by the CSRC be accomplished "publicly" and not internally as was the case with the 2007 Insider Trading Guidance Provisions. ${ }^{59}$

\section{The PRC Law on Legislation}

The 2000 PRC Law on Legislation (Law on Legislation), ${ }^{60}$ passed six years before the 2006 PRC Securities Law, strongly supports the present analysis insofar as it specifies the character and form of the

57. "Measures" (banfa) are a hold-over appellation for administrative regulation from the pre-reform and legal construction era. Another similar appellation still commonly in use is "tiaoli" often translated as "regulations." In 1956, Mao Zedong personally authorized the use of these documents (including articles (zhangcheng), regulations (tiaoli), and measures (banfa)) to work in the service of application of "law" or formal legal norms. See Perry Keller, Sources of Order in Chinese Law, 42 AM. J. CoMP. L. 711, 722-23 (1994).

58. The same Chinese characters as are used to describe the obligation of all administrative agencies with respect to their administrative rule-making and enforcement functions in the Administration According to Law Outline, supra note 4, at para. 5 (iii).

59. As noted infra notes 80-82, and text, the PRC Law on Administrative Punishments also requires that administrative enforcement be undertaken pursuant to publicly-promulgated administrative law norms.

60. Zhonghua Renmin Gongheguo Lifa Fa [PRC Law on Legislation] (promulgated by the Standing Comm. Nat'l People's Cong. and effective Mar. 15, 2000, 
required norms that must issue from the verb action "to regulate" or "to stipulate in regulation" (gui'ding)—laws, legislative provisions, laws and administrative regulations, administrative measures or specific (administrative) measures.

Article 9 of the Law on Legislation authorizes delegation by China's national legislature, the National People's Congress (NPC), or the NPC Standing Committee to the State Council and its departments the power to formulate (zhiding) ${ }^{61}$ "administrative regulations" (xingzheng fagui), the same Chinese character set that is often the result of the verb "to regulate" or "to stipulate in regulation" (gui'ding) in the 2006 PRC Securities Law. Importantly, that delegation is only effective when the NPC or its Standing Committee have not yet passed "law" on the various areas within its/their legislative competence (listed in Article 8 of the Law on Legislation). Articles 5662 of the Law on Legislation address such "administrative regulations." These statutory provisions make clear that these are norms conceived, discussed, and issued only by the State Council of the PRC, and not by any subordinate ministry, department or commission. Most importantly for the present discussion, such administrative regulations must be signed by the Premier, "publicly promulgated" (gongbu) in a State Council order, and then published in the State Council gazette. ${ }^{62}$

Articles 71-77 of the Law on Legislation address yet another genus of administrative norm, which are commonly translated as "departmental rules" (guizhang). These departmental rules are formulated by the State Council's subordinate departments (including ministries), commissions (including the CSRC), the People's Bank of China (China's central bank), the State Audit Commission, and subordinate organs with administrative competence, and must be "in accordance with law, and State Council administrative regulations (xingzheng fagui), decisions (jueding), and orders (mingling)." Each of the State Council's "subordinate departments, commissions, the People's Bank of China, the State Audit Commission and subordinate organs with administrative competence" are referred to in the Law on Legislation under the global term "departments" (bumen). ${ }^{63}$ Importantly, the Law on Legislation mandates that any "rules" formulated by such "departments" must be formulated in accordance with law, and must be "publicly promulgated" (gongbu) and published. ${ }^{64}$

effective July 1, 2000), available at $\mathrm{http}: / / \mathrm{www}$.lawinfochina.com/Display.aspx?lib= law \&ID $=386$.

61. This is the same verb form noted above that appears in the 2006 PRC Securities Law, see supra note 51, and text, and in the PRC Law on Legislation is used as a general verb to formulate various kinds of norms, including "law" (falü).

62. PRC Law on Legislation, supra note 60, arts. 61 and 62.

63. Id. art. 71.

64. Id. arts. 76 and 77. 
Pursuant to the terms of the Law on Legislation then ${ }^{65}$ - which makes no mention of "guidance" (zhiyin) or "guidance documents" (zhidaoxing wenjian) as a species of "administrative regulation" (xingzheng fagui) or any other kind of norm-the 2007 Insider Trading Guidance Provisions qualify neither as (i) "administrative regulations" (xingzheng fagui), nor as (ii) "departmental rules" (guizhang or bumen guizhang). They are not the former, because they are not formulated and issued by the State Council or made public (nor are they issued in the absence of legal stipulations on the same subject). They are not the latter because they are not publicly issued or published. As noted above, the 2007 Insider Trading Guidance Provisions are merely internal guidance for the CSRC in enforcement against insider trading, and have never been publicly promulgated and are not published on the CSRC website. In addition, they are norms which far exceed the bounds of the 2006 PRC Securities Law, and are thus anything but norms "formulated in accordance with law."

\section{Is the CSRC's 2007 Guidance a "Normative Document" (guifanxing wenjian)?}

Some may understand the CSRC's 2007 Insider Trading Guidance Provisions as what the Chinese legal and governance system calls a "normative document" (guifanxing wenjian), i.e., long-standing Chinese Communist Party-led state governance norms not formally recognized in the Law on Legislation. In the PRC, the term has historically been used for the many non-legal norms enforced in fact, including everything from line ministry or local People's Congress norms to specifically-tailored bureaucratic communications and institutional or personal approvals. ${ }^{66}$ Even after the promulgation of the Law on Legislation, which does not refer to such norms, the term is still used in government and departmental pronouncements-like the State Council's 2004 Administration According to Law Outline ${ }^{67}$ and 2010 Rule of Law Government Opinion ${ }^{68}$-in concrete acknowledgement of the fact that many such non-legal, non-regulatory,

65. Promulgated more than a decade before the PRC Law on Legislation, the PRC Administrative Litigation Law, infra note 72 , in describing the kinds of administrative acts or norms that can and cannot be subject to challenge, also refers to "administrative regulations" (xingzheng fagui) and "departmental rules" (guizhang) with the same terminology (Articles 12(2) and 53). In addition, the PRC Administrative Litigation Law refers to "decisions" (jueding) and "orders" (mingling) "formulated and announced by administrative organs with universal binding force" (Article 12(2)). There is no mention in the PRC Administrative Litigation Law of a norm called "guidance" (zhiyin) or "guidance documents" (zhidaoxing wenjian) as a species of "administrative regulation" or "departmental rules."

66. See Keller, supra note 57, at 722-23.

67. See, e.g., Administration According to Law Outline, supra note 4, paras. 3(ii) and 14.

68. See, e.g., Rule of Law Government Opinion, supra note 6, paras. 8-10. 
norms continue to exist and continue to be applied by various state actors and Communist Party officials.

All of the above notwithstanding, the CSRC's 2007 Insider Trading Guidance Provisions are still defective and unenforceable, even if understood as a "normative document." This is because: (i) the 2006 PRC Securities Law does not authorize issuance of such normative documents for the further enumeration of PWKII, but instead calls for the issuance of legislative provisions, administrative regulations, or administrative measures; (ii) the CSRC Guidance Provisions do not comply with the basic requirements for issuance of apparently enforceable normative documents (that they be issued publicly, and are subject to the "file and review" (bei'an shencha) procedure);69 and (iii) as demonstrated here, the substantive content of the Insider Trading Guidance Provisions is ultra vires and wildly out of conformity with China's explicit statutory provisions on insider trading.

\section{What are "Guidance Documents" (zhidaoxing wenjian) Anyway?}

The CSRC's 2007 Insider Trading Guidance Provisions declare themselves to be a "guidance document" (zhidaoxing wenjian). This self-declaration begs the question as to what exactly such "guidance documents" are. Most importantly in the present context, can they qualify as legislative provisions, administrative regulations, administrative measures, or even departmental rules that are responsive to the 2006 PRC Securities Law Article 74(vii) mandate, or as enforceable legal-regulatory norms under the Law on Legislation?

In fact, there is no reference whatsoever to such "guidance documents" in any national PRC law or administrative regulation, and certainly not in the Law on Legislation; instead, there is only the exhortation for "administrative guidance" (xingzheng zhidao) in various departmental rules. These exhortations are a reflection of the State Council's allusion to the same item in its 2004 Administration According to Law Outline. ${ }^{70}$

The only, partial, reference to the concept of administrative "guidance" comes in Article 1(4) of the Supreme People's Court's 2000 interpretation ${ }^{71}$ of the 1989 Administrative Litigation Law (Adminis-

69. Required under the 2004 Administration According to Law Outline and the 2010 Rule of Law Government Opinion, supra notes 4 and 6.

70. See Administration According to Law Outline, supra note 4.

71. Zuigao Renmin Fayuan Guanyu Zhixing "Zhonghua Renmin Gongheguo Xingzheng Susong Fa" Ruogan Wenti De Jieshi [Supreme People's Court Interpretation of Certain Issues in the Implementation of the PRC Administrative Litigation Law] (passed by the Sup. People's Ct. Adjudication Comm. Nov. 24, 1999, promulgated by the Sup. People's Ct. Mar, 8, 2000, and effective Mar. 10, 2000), available at http://vip.chinalawinfo.com/NewLaw2002/SLC/SLC.asp?Db=chl\&Gid=26982 [hereinafter Administrative Litigation Law Interpretation]. 
trative Litigation Law), ${ }^{72}$ which stipulates that "administrative guidance acts (xingzheng zhidao xingwei) that do not possess coercive force (qiangzhili)" are not justiciable under the Administrative Litigation Law. The negative implication of that provision is that "administrative guidance acts" that do have coercive force are justiciable under the Administrative Litigation Law. While that notion may be helpful for a private party wishing to challenge any CSRC enforcement pursuant to the 2007 Insider Trading Guidance Provisions alone, it provides no help in making such "administrative guidance acts" (which may include internal issuance of a "guidance document" like the CSRC's 2007 Insider Trading Guidance Provisions) qualify as legislative provisions, administrative regulations, administrative measures, or even departmental rules apparently required under the 2006 PRC Securities Law or the Law on Legislation.

\section{Conclusion as to Regulatory and Administrative Law Infirmity of the Insider Trading Guidance Provisions}

The simple conclusion of the foregoing analysis is this: the CSRC, by issuing the 2007 Insider Trading Guidance Provisions, has not created a legal or regulatory norm which conforms to the statutory authorization in Article 74(vii) of the 2006 PRC Securities Law to "regulate" or "stipulate in regulation" (gui'ding) "other" PWKII.

First, as demonstrated above, the statutory command to the CSRC in Article 74(vii) of the 2006 PRC Securities Law is to issue what the Securities Law and the Law on Legislation would limit to legislative provisions, administrative regulations, departmental rules or administrative measures regarding the other actors who can be identified as PWKII. Instead, the CSRC distributed internally a different species of direction called "(provisional) guidance (zhiyin) on the recognition and confirmation (ren'ding)" of insider trading behavior; ${ }^{73}$ it self-identifies as a "guidance document" (zhidaoxing wenjian) for use by CSRC officials only to "recognize and confirm insider trading."74 Moreover, that guidance-by its own terms-is based in, or authorized by, a cluster of norms it is itself supposed to be: "the Securities Law, and the related provisions of other laws, administrative regulations (xingzheng fagui) and departmental rules (guizhang)."75 How, one might ask, can a norm (called "guidance") be an "adminis-

72. Zhonghua Renmin Gongheguo Xingzheng Susong Fa [PRC Administrative Litigation Law] (promulgated by Nat'l People's Cong. Apr. 4, 1989, effective Oct. 1, 1990), available at http://www .lawinfochina.com/Display.aspx?lib=law\&ID=1204.

73. Which seems more directly responsive to the 2006 PRC Securities Law Article 75(viii) invitation to "recognize and confirm" (ren'ding) price-moving inside information.

74. Insider Trading Guidance Provisions, supra note 20, art. 4.

75. Id. art. 1 . 
trative regulation" or "rule" authorized by the superior norm it is supposed to be-"administrative regulation" or "rule"-by the terms of the delegating law?

Second, and equally importantly, the CSRC 2007 Guidance is not public, which under the Law on Legislation all administrative regulations (xingzheng fagui) and departmental rules (guizhang), and under the 2006 PRC Securities Law all departmental rules and rules (guizhang, guize), must be. Permitted to "regulate" or "stipulate in regulation" (gui'ding) a very specific norm, in 2007 the CSRC produced something internally which is not responsive to, and does not conform to, that authorization.

\section{B. The 2007 Insider Trading Guidance Provisions are Ultra Vires}

The Insider Trading Guidance Provisions, whatever their standing as administrative regulation or departmental rules, and even if they had been issued "publicly," are ultra vires. The Provisions proclaim that they are formulated in accordance with "the Securities Law, and the relevant provisions of other laws, administrative regulations and rules." 76 This is a falsehood, and the Insider Trading Guidance Provisions are demonstrably ultra vires on two counts:

First, the CSRC Provisions address matters far beyond the narrow grant of regulatory authority in Article 74(vii) of the 2006 PRC Securities Law-limited to designation of "other" PWKII.

Second, they are ultra vires with respect to the entire legal understanding of insider trading under the Securities Law, because they re-define the civil breach and eventually the crime. As demonstrated in Part II.B. above, the liability for insider trading set forth in the CSRC's 2007 Insider Trading Guidance Provisions departs radically and completely from the limited bases for insider trading under the 2006 PRC Securities Law. The CSRC Insider Trading Guidance Provisions provide for (in U.S. securities law parlance) a Texas Gulf Sulphur theory of liability (covering anyone in possession of inside information who trades), whereas the 2006 PRC Securities Law allows only a narrow version of (again in U.S. parlance) Cady, Roberts / Chiarella liability (covering only the specific actors identified in Article 74) and what obviously aspires to be O'Hagen-style misappropriation liability.

\section{A Distinction that Explains the Problem: Article 77 "Securities Trading Manipulation" Unaffected}

A short tangent regarding another 2006 PRC Securities Law breach, similar to the insider trading prohibition, may aid in under-

76. Id. 
standing how and why the CSRC is in such a difficult spot with respect to insider trading.

Article 77 of the 2006 PRC Securities Law describes the separate breach of "securities trading manipulation." Yet there, the CSRC would be-and indeed is ${ }^{77}$ - perfectly in compliance with the law in using internal guidance for enforcement against such market manipulation. This is because Article 77(iv) provides a broad catch-all against "other methods of securities market manipulation" without specific required elements to make out "manipulation" (such as scienter, purchase or sale of securities, etc.), and Article 77 makes no specific delegation of regulatory power to the CSRC or any other agency for further elaboration or description. The statute is silent, and the CSRC's discretion apparently unbounded.

Accordingly, the CSRC is free under the statute to proceed against such manipulation in any way it determines, and without reference to any notified or universally applicable administrative law norm-something I argue it cannot do with respect to insider trading. The situation described in this Article is very different: for insider trading there is a detailed statutory structure informing the elements of the breach (and the scope of the prohibition), and two very limited commands to the regulator to provide elaboration-the mandate to "regulate" or "stipulate in regulation" "other" PWKII, and the authorization to "recognize and confirm" (ren'ding) important information having a significant effect on securities prices. ${ }^{78}$ Under the governing statute, the CSRC simply does not have the leeway with respect to insider trading that it has with respect to the separate breach of securities trading manipulation.

\section{Enforcement Abuse}

Unfortunately, the significant problem identified and analyzed here is not just a theoretical one. The CSRC is actively enforcing insider trading liability under the very wide theory promised by the defective 2007 Insider Trading Guidance Provisions, and in situations where the 2006 PRC Securities Law does not cover the

77. Which the CSRC did at the same time it distributed internally the defective Insider Trading Guidance Provisions in 2007. See the CSRC's Securities Trading Manipulation and Insider Trading Guidance Notice, supra note 20.

78. The analysis here might lead to the conclusion that the CSRC is also free to determine what constitutes price-impacting information for insider trading enforcement without issuing formal regulation or rules, because Article 75(viii) of the 2006 PRC Securities Law merely requires that the CSRC "recognize and confirm" (ren'ding) what that information is in specific circumstances. In fact, the 2007 Insider Trading Guidance Provisions do set forth ways in which the CSRC is to "recognize and confirm" such information in the context of an insider trading enforcement action. Working against this forgiving conclusion is the general requirement in Articles 179 and 184 of the 2006 PRC Securities Law, noted above, that the CSRC formulate "departmental rules" or "rules" (guizhang, guize), and that they do so "publicly." 
sanctioned behavior. Authoritative PRC academic analysts note this, ${ }^{79}$ and a glance at recent enforcement decisions posted on the CSRC website makes this abundantly clear (summaries of the examples referred to immediately below appear in Appendix I).

The 2011 Liu Yang enforcement decision shows how liberally the CSRC misapplies Article 74 of the 2006 PRC Securities Law, in that the defendant is pronounced a PWKII simply because he "participated in ... [the reverse merger] related affairs." This is not what is provided for under Article 74(iv) ("persons who are able to obtain relevant inside information concerning the company by virtue of the position they hold in the company"), which is unavailable precisely because the defendant comes into possession of important information about a company-the target-different from the one he is employed at. Nor does the CSRC make any effort to base the defendant's liability in the misappropriation prong of the statute. Without any doubt, in this case the CSRC relies upon the wider basis for insider trading liability in the 2007 Insider Trading Guidance Provisions because it cannot make out a claim under the governing statute.

In the 2011 Lin Shiquan enforcement action, the CSRC does not indicate how the defendant qualifies as one of the PWKII enumerated in Article 74 of the 2006 PRC Securities Law, stating only that he "became" a PWKII. He is not identified as an officer or shareholder of the controlling shareholder of the issuer, although he is identified as the top executive of another entity which may be a shareholder of the issuer holding more than five percent of the issuer under Article 74(ii) of the Securities Law. Nowhere in the decision does the CSRC feel the need to articulate how this defendant qualifies as a PWKII, or if he is guilty of misappropriation of the information, no doubt because they are relying upon the broader basis for insider trading liability provided for in the 2007 Insider Trading Guidance Provisions.

In the 2010 Jia Huazhang \& Liu Rong decision regarding a fairly standard husband-wife/tipper-tippee case, the CSRC simply declares the husband/tipper to be a PWKII without tying his status to the enumerated persons under Article 74. Nor does the CSRC independently identify him as someone who has misappropriated inside information under Articles 73 and 76. He may be a tipper of material, non-public,

79. See Ye Lin, Neimu Xinxi De Falü Guanzhi [Insider Trading Legal Regime], in ZhengquanFa JiaOcheng [Securities Law] 319 (Ye Lin, Duan Wei, Wang Shihua \& Wang Huajie eds., 2010) ("The [Insider Trading Guidance Provisions] clearly stipulate that where insider trading with respect to any exchange-issued or -listed securities is identified, the [Insider Trading] Guidance Provisions are to be applied. If insider trading is identified on any other State Council-approved securities exchange, enforcement is to be implemented with reference to the [Insider Trading] Guidance Provisions."). 
information, but because he is neither a PWKII nor guilty of misappropriation, he is not subject to the tipping prohibition under Article 76. Thus, as a person who has merely come into possession of inside information, it is unclear how he is an insider trading defendant under the law, unless the CSRC is using the broader basis for enforcement provided for under the 2007 Insider Trading Guidance Provisions. Second, the wife is a tippee-trader of inside information, and again the CSRC makes no connection between her possession of the information and any kind of misappropriation of inside information. Again, she is not an appropriate defendant under Article 76 of the PRC 2006 Securities Law, and the only way in which the CSRC can accomplish enforcement against her is extra-legally via the 2007 Insider Trading Guidance Provisions.

If nothing else, these readily available examples of extra-legal administrative enforcement demonstrate clear violations of the 1996 PRC Law on Administrative Punishments, which forbids the imposition of such punishments without a statutory basis, ${ }^{80}$ makes invalid administrative punishments imposed not in accordance with law, ${ }^{81}$ and forbids the imposition of administrative punishment under law other than in accordance with publicly-promulgated norms. ${ }^{82}$

There remains a more serious question as to whether the PRC People's Procuratorate-China's criminal prosecutor-is also using the all-embracing Insider Trading Guidance Provisions to establish the elements of the crime of insider trading via Article 180 of the PRC Criminal Law, resulting in the imprisonment and deprivation of the political rights of certain securities traders. Unfortunately, the real picture of insider trading criminal enforcement under Article 180 of the Criminal Law is obscured because criminal judgments in the PRC are not publicized or reasoned in the way most civil and administrative law cases are. Instead, criminal defendants are simply reported by the government or media to be guilty of "insider trading" and subject to criminal punishment. ${ }^{83}$ Given the CSRC's very cavalier attitude towards extra-legal insider trading enforcement in the administrative sphere, it is not unreasonable to think that the People's Procuratorate-as advised by the expert agency charged with enforcement, the CSRC-also uses the defective Insider Trading Guidance Provisions as the basis for criminal enforcement.

80. PRC Law on Administrative Punishments, supra note 3, art. 55.

81. Id. art. 3(ii).

82. Id. art. 4(ii).

83. See, e.g., the 2007-8 reports of criminal insider trading breaches by New China Life Insurance Chairman Guan Guoliang and Guomei Electronics founder Huang Guangyu. See Yu Ning, Su Dandan \& Li Minhua, 'Neiburen" Guan Guoliang ["Insider" Guan Guoliang], CAIJING, May 28, 2007, at 40-50; and Yu Ning, Li Qing \& Luo Chanping, Huang Guangyu Wu [The Huang Guangyu Fog], CAIJING, Dec. 8, 2008, at 96-104. 


\section{Challenges to the Enforcement of Illegal Norms}

It is one thing to assert, pursuant to a close analysis like the one here, that the CSRC's 2007 Insider Trading Guidance Provisions should be understood as void and unenforceable. It is another thing to understand what real (i.e., actually applicable) externally-imposed constraints there are on the enforcement of norms like these in the contemporary Chinese legal system. Potential external constraints are significant indicia of what can be termed a "rule of law" system as contrasted with a "rule by law" system: If any state actor (or indeed anyone with a monopoly on coercive power) is able to articulate and apply norms against citizens and corporate entities with no basis in the law, or norms which conflict with or exceed the scope of law and legal norms, then rule $b y$ law is being implemented. If, instead, state actors (or, again, anyone with an apparent monopoly on coercive power) can be checked by an external force or institution in their attempted assertion of norms with no basis in the law, or which conflict with or exceed the scope of law and legal norms, then there are at least the beginnings of rule of law.

Certainly, the Party-state government of the PRC has understood this in some measure and in certain sectors (all, alas, outside of the criminal law sphere). Precisely "why"-whether to conform to some idea of "modernity" or to maintain legitimacy, or by some other calculation-remains a deeply contested point and is beyond the scope of this Article. Suffice to say that this political-legal understanding explains the multiple exhortations over the past decade by the PRC State Council urging "administration according to law," forbidding state administrative action not authorized in law, condemning state administrative action that is ultra vires, and encouraging the application of legally-stipulated constraints on state administrative power. As the State Council states up front in its 2010 policy document, "administration according to law (yifa xingzheng) is a key component of rule of law (yifa zhiguo)." 84 At the same time these exhortations indicate that the status quo ante in China at present is anything but "administration according to law."

Accordingly, the analysis undertaken in this Part V is significant not only for a better understanding of China's securities regulatory regime, but of critical importance for an understanding of the possibilities for, and application of, legal norms in the service of "rule of law" for China's national governance system. In this section I briefly outline possible external checks available both to appellate institutions (agency and judicial) and to private actors who have illegal norms visited on them. I present these challenges with respect to: (i)

84. Rule of Law Government Opinion, supra note 6, art. 1. 
the enforceability of non-legal, non-regulatory, norms; (ii) administrative enforcement; and (iii) criminal enforcement.

Notwithstanding the State Council's encouragement of private challenges seeking to hold administrative agencies in check or accountable and promote "administration under law" and "rule of law government," one must note the extreme difficulty of pursuing such private challenges given the peculiar architecture of China's system for the review of administrative norms and criminal law, abstract or as applied. Indeed, the serious difficulties tied to establishment of a legal claim against the Insider Trading Guidance Provisions, and their enforcement, can make a jaded analyst conclude that the CSRC purposely designed its basic insider trading enforcement regime so as to insulate it from any external, legal, check. Accordingly, the greater hope for such checks must continue to lie with China's developing judiciary, acting under its own institutional power to block or overturn asserted administrative (or criminal) enforcement. ${ }^{85}$

\section{A. Enforceability of the Insider Trading Guidance Provisions qua Non-legal and Non-regulatory Norms}

With regard to the "legal force" of the Insider Trading Guidance Provisions, Professor Cui Wei of the China University of Politics and Law has argued that the Law on Legislation suggests that legal and regulatory norms not addressed in that statute do not "have the force of law."86 Professor Cui also highlights the PRC judiciary's consistently articulated view of what norms are enforceable before the courts, distinguishing between "formal regulations" (which are) and "interpretations for specific application" and "normative documents" (which are not). In support, he cites the Supreme People's Court statement from a 2003 national judicial conference in Shanghai that although "agencies frequently rely on such interpretations . . . and other normative documents as the basis for specific administrative actions," they are not "formal sources of law, and do not have the binding force of legal norms." 87 As Professor Cui concludes:

85. As I have written elsewhere, this hope is not entirely baseless given the dynamic development seen in contemporary Chinese law and society, and the PRC's economic and governance systems, at least in sectors less central to the Communist Party's continuing rule and its paramount mission of social and political control. See Nicholas Calcina Howson, Corporate Law in the Shanghai People's Courts, 1992-2008: Judicial Autonomy in a Contemporary Authoritarian State, 5 E. AsiA L. REv. 303 (2010).

86. See Cui, supra note 7 , at 78 ("While the statute does not state anywhere that no other type of documents issued by government entities have the force of law and that the rules governed by it are the exclusive sources of law, it strongly implies so. This is because the central purpose of the [Law on Legislation] is to bring consistency and uniformity to the Chinese legal system, and its ability to do so would be severely limited if rules with the force of law are not governed and ordered by it.").

87. Id. at 82, citing to "Meeting Minutes Regarding the Application of Legal Norms in Reviewing Administrative Cases" (Sup. People's Ct. Doc. fa (2004) No. 96, 
The message of the [2003] Shanghai Meeting Minutes seems clear: government pronouncements with lesser authority than regulations are not legally binding, and will be given effect only at a court's discretion. This message is also entirely consistent with the [Law on Legislation's] view of what has the force of law.

A useful adjunct to Professor Cui's argument-applicable to both administrative decisions and court judgments-is the PRC Supreme People's Court's October 2009 directive which prohibits any administrative agency or court from citing in any decision to (i.e., basing its adjudication on) norms such as the Insider Trading Guidance Provisions. ${ }^{88}$ This directive may be the reason why the CSRC administrative enforcement decisions analyzed here do not refer to the Insider Trading Guidance Provisions even when the subject insider trading breach can only be made out under the Guidance Provisions and not the governing statute. ${ }^{89}$

Thus, even assuming for a moment that the Insider Trading Guidance Provisions conform to the regulatory command in the 2006 PRC Securities Law and that they are not ultra vires, there is a theoretical argument that the Guidance Provisions, as a species of norm inferior to "regulations," can be understood as potentially unenforceable, or as merely enforceable at the discretion of a PRC court. The argument is relatively weak, however, precisely because of the widespread and continuing use and enforcement of sub-legal or subregulatory norms, including the large volume of "normative documents," in contemporary China.

\section{B. Challenges to Administrative Enforcement}

Under Chinese law, facial challenge or abstract review of administrative norms can be applied via at least three channels: administrative reconsideration, administrative litigation, or in the criminal enforcement sphere and where the judiciary is involved under the Law on Legislation.

issued by the Sup. People's Ct., May 18, 2004), at sec. 1. Cui Wei continues: "Nonetheless, if a court, when adjudicating a case relating to specific administrative actions, determines that such interpretation or normative document possesses 'legal validity, effectiveness, reasonableness and appropriateness,' it may give effect to such interpretation or document in determining whether the specific administrative act has a legal basis."

88. See Zuigao Renmin Fayuan Guanyu Caipan Wenshu Yinyong Falü, Fagui Deng Guifanxing Falü Wenjian De Guiding [Supreme People's Court Regulations Regarding Citation of Laws, Administrative Regulations, Normative Legal Documents, etc. in Judgment Opinions] (passed by the Sup. People's Ct. Adjudication Comm. July 13, 2009, promulgated by the Sup. People's Ct. and effective, Nov. 4, 2009), available at http://www.law-lib.com/law/law_view.asp?id=300043 [hereinafter, Supreme People's Court Citation Regulations].

89. See supra Part IV, and Appendix I infra. 
A kind of abstract review of administrative norms is permitted in China for parties subject to enforcement pursuant to the administrative reconsideration (xingzheng fuyi) process under the PRC Administrative Reconsideration Law (ARL). ${ }^{90}$ The ARL allows for reconsideration of certain norms that are alleged to be "illegal" ( $b u$ hefa de). ${ }^{91}$ However, abstract reconsideration can only be applied to "legislative provisions of State Council departments" (guowuyuan bumen de gui'ding) and not to "State Council departmental or commission rules" (guowuyuan bu, weiyuanhui guizhang). Because the 2007 Insider Trading Guidance Provisions do not rise to the level of "departmental or commission rules" (guizhang), much less "legislative provisions" (gui'ding), the CSRC Guidance Provisions would seem to fall outside of the scope of administrative or regulatory norms subject to reconsideration under the ARL.

The Administrative Litigation Law proves equally unhelpful for private claims seeking to challenge any properly-issued administrative norms on their face, because that Law provides no affirmative legal basis for abstract review of such norms by the PRC judiciary (permitting only judicial review of specific administrative acts). ${ }^{92}$

There is the possibility of abstract review under the Law on Legislation, but it does not entitle private claimants. The Law on Legislation mechanism is grounded in Article 88(3) of that statute, under which the PRC State Council has the power to annul any departmental rules that are "inappropriate."93 This architecture makes initiatives difficult in the present context for at least two reasons. First, to qualify as the object of a Law on Legislation Article 88(3)based State Council annulling, the Insider Trading Guidance Provi-

90. Zhonghua Renmin Gongheguo Xingzheng Fuyi Fa [PRC Administrative Reconsideration Law] (promulgated by the Standing Comm. Nat'l People's Cong., Apr. 29, 1999, effective Oct. 1, 1999, amended by Nat'l People's Cong., Aug. 27, 2009), available at http://www.lawinfochina.com/Display.aspx?lib=law\&ID=5279. In 2010, the CSRC issued an Order No. 69, its own "Measures for Administrative Reconsideration" (issued by the CSRC May 4, 2010, effective July 1,2010), available at http:// www.csrc.gov.cn/pub/zjhpublic/G00306201/201005/t20100505_180043.htm. The CSRC measures only address reconsideration of specific administrative acts (per Article 6 of the PRC Administrative Reconsideration Law), and do not countenance the abstract administrative reconsideration authorized in Article 7 of the PRC Administrative Reconsideration Law.

91. See PRC Administrative Reconsideration Law, supra note 90, art. 7.

92. See The PRC Administrative Litigation Law, supra note 72, art. 12, and Supreme People's Court Administrative Litigation Law Interpretation, supra note 71, art. 3, and infra notes 97-98, and text.

93. Those hoping for a PRC-style constitutional challenge will be disappointed. There is no possibility the Insider Trading Guidance Provisions can be annulled by the NPC Standing Committee under Article 88(2) of the Law on Legislation after a "citizen proposal" under Article 90(2) of the Law on Legislation, because the CSRC Insider Trading Guidance Provisions are created by a department/commission under the PRC State Council, and thus are not "administrative regulations" issued by the State Council itself (xingzheng fagui), the latter being the proper subject of Law on Legislation Articles $90(2)$ and 88(2) constitutional review claims and procedures. 
sions would have to be understood as "departmental rules" (guizhang) under the scheme set forth in the Law on Legislation. I have demonstrated above why the Guidance Provisions do not in any way qualify as "departmental rules." Second, the Law on Legislation does not permit a private action in connection with State Council review of departmental rules. Instead, the State Council acts sua sponte, and only after "filing for the record" (bei'an) of a given departmental rule with the State Council, and then examination of it by the State Council at the State Council's option. Thus, it would be entirely up to the State Council, on its own initiative, to declare that the Insider Trading Guidance Provisions are "inappropriate" on their face for the reasons described in this Article-a weak and not very "external" constraint.

Challenge or review of concrete administrative enforcement acts by the CSRC pursuant to the Insider Trading Guidance Provisions holds somewhat greater promise.

First, under the ARL an insider trading defendant can apply for "reconsideration" of a concrete administrative sanction (including a fine or confiscation of illegal gains or property) or a compulsory administrative measure (including the sealing, seizing or freezing of property). ${ }^{94}$ Administrative enforcement of the insider trading prohibitions by the CSRC usually involves both concrete administrative sanctions (disgorgement of unjust enrichment and payment of fines) and compulsory administrative measures (sealing and seizing). The 2008 Regulations of the PRC on Open Government Information also encourage-but do not provide a legal basis for-administrative reconsideration if "citizens . . . believe [that] a specific administrative action of an administrative agency in its open government work has infringed their lawful rights and interests." ${ }^{95}$ Similarly, the PRC Law on Administrative Punishments ${ }^{96}$ provides a legal basis for reconsideration of administrative punishments. Of course, any ARL-based reconsideration claim will be hampered by the fact that such reconsideration is effected by the same administrative agency being challenged, i.e., the CSRC.

Second, the Administrative Litigation Law provides for private claims challenging the legality of specific administrative acts. In this case, there would be two claims by any party against which illegal enforcement has been effected: (i) that the Insider Trading Guidance Provisions are a type of norm that does not have legal force; ${ }^{97}$ and (ii)

94. PRC Administrative Reconsideration Law, supra note 90, art. 6. As noted above, supra note 90, the CSRC's own reconsideration measures only address reconsideration of specific administrative acts. $33(2)$.

95. Regulations of the PRC on Open Government Information, supra note 5, art.

96. PRC Law on Administrative Punishments, supra note 3, art. 6.

97. See supra notes 86-87, and text. 
that the concrete act (i.e., any specific administrative enforcement of the Insider Trading Guidance Provisions) is in conflict with the 2006 PRC Securities Law structure for insider trading and is in violation of the PRC Law on Administrative Punishments. ${ }^{98}$ The Regulations of the PRC on Open Government Information and the PRC Law on Administrative Punishments encourage administrative litigation in just this situation. However, any administrative litigation attack against a CSRC fine or forced disgorgement of ill-gotten gains would have to employ the concept articulated in the Supreme People's Court's 2000 Administrative Litigation Law Interpretation making "administrative guidance acts possessing coercive force" justiciable. Only if penalties levied pursuant to the Insider Trading Guidance Provisions are understood as "administrative guidance acts possessing coercive force" could they be challenged under the Administrative Litigation Law. This line of attack could present difficulties for claimants, because enforcement based solely on the Insider Trading Guidance Provisions is not action resulting from or related to an $a d-$ ministrative guidance act, but instead a departmental or commission guidance act.

\section{Challenges to Criminal Enforcement}

In the criminal law and enforcement sphere, there appears to be little chance of abstract review of the Insider Trading Guidance Provisions as a norm inconsistent with law or the Constitution. Abstract review under the ARL reconsideration process would not be available because there is no administrative norm at issue (the challenge would focus on the application of Article 180 of the PRC Criminal Law, albeit as strongly informed by the Insider Trading Guidance Provisions). As noted above, abstract review is not available under the Administrative Litigation Law even where there is an identifiable administrative norm being used, and the Administrative Litigation Law does not in any case address enforcement of criminal norms.

An attack against concrete application of the Insider Trading Guidance Provisions in the criminal context (via Article 180 of the PRC Criminal Law) looks more promising. If indeed criminal penalties are imposed pursuant to the non-public and ultra vires Insider Trading Guidance Provisions, then that specific instance of criminal enforcement will be in violation of a host of important PRC legal

98. For the reasons set forth at supra notes 80-82, and text (forbidding administrative punishments imposed without a statutory basis, invalidating administrative punishments imposed not in accordance with law, and mandating imposition of administrative punishments only in accordance with publicly-promulgated norms). 
norms, including the Law on Legislation, ${ }^{99}$ the PRC Criminal Law, ${ }^{100}$ and the PRC Constitution. ${ }^{101}$

In fact, in criminal enforcement a specific challenge seeking a judicial declaration that the 2007 Insider Trading Guidance Provisions are "void" is not even necessary. On appeal and re-hearing, a PRC court would simply decline to apply the Insider Trading Guidance Provisions or overturn their application in the first level adjudication, and reverse the conviction. ${ }^{102}$

The difficulty of any such challenge arises from the context in which it would be made - on appeal by a detained defendant who admits some kind of insider trading, just not the insider trading specifically described in the 2006 PRC Securities Law (and by extension the PRC Criminal Law). The relative lack of legal sophistication, and the radical imbalance of power, understood to persist in the criminal enforcement context in China means that the criminal defendant, or his or her counsel, might have a very difficult time raising such a complex challenge on appeal, and an even greater problem having it understood and acted upon by the Procuratorate and the sitting judges (or the political-legal and adjudication committees behind them).

\section{CONCLUSION}

To my knowledge, neither the 2007 Insider Trading Guidance Provisions nor any enforcement of the insider trading prohibition pursuant to the Insider Trading Guidance Provisions has ever been subject to challenge or reversal in the civil or criminal spheres. ${ }^{103}$ This can mean several things. While the possible legal claims are of varying strength and feasibility, one can conclude that in China there is a continuing high tolerance for the enforcement of defective and illegal norms in the securities regulation sphere (as well as in other areas of administrative governance).

The basic illegality underlying China's insider trading prohibitions and enforcement analyzed in this Article, the failure of the

99. PRC Law on Legislation, supra note 60 , arts. 8 and 9 state that measures and punishments that deprive citizens of their political rights or restrict their personal freedoms can only be established in law.

100. PRC Criminal Law, supra note 17 , art. 3 , which provides that "[f]or acts that are explicitly defined as criminal acts in the [Criminal] Law, the offenders shall be convicted and punished in accordance with law; otherwise they shall not be convicted or punished" (emphasis added).

101. Zhonghua Renmin Gongheguo Xianfa [Constitution of the PRC] art. 37 (1982), which mandates that the deprivation or restriction of citizens' personal freedom must be pursuant to "law."

102. Here, any appellate court reviewing a criminal judgment rendered pursuant to the Insider Trading Guidance Provisions could also rely on the Supreme People's Court Citation Regulations, supra note 88 , which prohibit a court from citing to the Insider Trading Guidance Provisions to convict or uphold a conviction.

103. See supra notes $94-98$, and text. 
specific administrative agency with jurisdiction to remedy the situation, ${ }^{104}$ and the high level of tolerance shown by market participants subject to such illegal enforcement, all provide important insights regarding China's efforts to establish even thin "rule of law" after more than three decades. This is especially apparent because the rulemaking and ultra vires defects in this particular case are so egregious, and have been visited upon relatively sophisticated, welleducated, largely urban, property rights-wielding investors, and because the regulated transactions are economic and financial, not political or oppositional in nature. Contrast the situation described here with the distinct circumstance seen throughout China, where local authorities assess "fees" or "taxes" pursuant to ad hoc commands not based in formal law or regulation, and extract huge sums from ill-educated, relatively cowed, peasant populations. In that alternate world, we might expect autocratic behavior from the local government. More importantly, we might also expect that autocratic behavior to be met with relative passivity by the governed, with no dispute from either side regarding a "legal basis" for the exaction, conformity of government behavior with legal or regulatory authorization, or due process, transparency, consistency, predictability, and real constraints on the government (at least until the charges aggregate to an unsustainable burden, whereupon the recourse is not to law, but "mass action").

From the agency or CSRC side, the phenomenon described here affirms intimations of a continuing top-down, policy-based, enforcement-directed and largely unaccountable orientation among the PRC's government administration units, acting in ways reminiscent of the imperial-era magistrate. At this time, one can only speculate as to why the CSRC-China's most "modern," politically independent and technically competent regulator-chose in 2007 to establish and then enforce non-public and clearly ultra vires extra-legal norms like the Insider Trading Guidance Provisions. Perhaps, as implied above, it did so precisely in order to seize the broadest possible scope of enforcement power while insulating the defective norms from legal challenge. Or perhaps, and now focusing on the failure to make "public" the ultra vires enforcement norms, it is a throwback to the longstanding distaste for the codification of laws in pre-imperial and imperial China. ${ }^{105}$ At first glance, this possibility may seem absurd, but

104. As all administrative agencies have been urged to do since 2004, and as the State Taxation Administration under the PRC Ministry of Finance did in its separate sphere in July 2010. See Administration According to Law Outline, supra note 4, and Cui, supra note 7 , at 89-94.

105. Embodied in pre-Confucian Shu Xiang's alleged sixth century BCE letter to Legalist tradition-law drafter $\mathrm{Zi}$ Chan recorded in the third century $\mathrm{BCE}$ compilation known as the Zuo Zhuan [Commentary Of Zuo]. See Derk Bodde's translation (based on Legge's original translation) at DERK BODde \& Clarence MORRIS, LAW IN IMPERIAL China: Exemplified by 190 Ch'ing Dynasty Cases 16-17 (1967). The same ideas 
even if one ignores the long tradition of discretionary application of non-public norms through the imperial era and China's post-1928 and post-1949 single party regimes-just this attitude was invoked in 2007 by Shenzhen stock exchange officials: when asked to explain why standards determining market misconduct were not made public, these officials pointed to the lack of sophistication of the Chinese capital markets, and said that "if the companies were aware of the specific standards, they might manipulate their disclosure so as to avoid sanctions." 106 Regardless of why the CSRC created the Insider Trading Guidance Provisions in the way they did, the fact that the problem appears under the administration of the CSRC means it can be assumed to exist even more in the approaches taken by older-line agencies and departments. ${ }^{107}$

What does this illegality in the design and enforcement of insider trading in China signify more broadly for the Chinese legal system? Carl Minzner and a number of other scholars and journalists have identified China's "turn against law" in recent years. ${ }^{108}$ In my view, the problem highlighted in this Article does not fit well into the "turn against law" account, even assuming it is accurate. Several reasons militate against such an account. First, the insider trading enforcement problem has nothing to do with the major focus of the "turn against law" complaint-broad central, state or Communist Party rhetoric about law and legal institutions, the desired politicization and adherence to a "mass line" of those institutions, or the way in which formal legal institutions are said to operate-and everything to do with how an expert agency actually applies the law and delegated power in a technically complex area way below the radar of public perception or macro-level political-legal discourse. Even in application, the insider trading enforcement problem does not evidence de-legalization or any rejection of law, but instead misapplication of law or legally-delegated authority. Second, the illegal design and enforcement of the CSRC's insider trading prohibition in China existed long before the largely rhetorical "turn against law" presently lamented, and therefore seems more firmly rooted in long-held (imperial era-origin) and continuing understandings about the power

made it a crime to have access to, or possess texts of, the penal law in the Song Dynasty (960-1279 C.E.). See Miyazaki Ichisada, The Administration of Justice During the Sung Dynasty, in Essays ON ChINA's LeGAL Tradition 56-75 (Jerome A. Cohen et al. eds., 1980).

106. See Liebman \& Milhaupt, supra note 9, at 950.

107. And is known to exist in the tax administration sphere. See Cui, supra note 7.

108. See Carl Minzner, China's Turn Against Law, 59 Aм. J. Comp. L. 935 (2011) (focusing on central rhetoric about recourse to law and the politicization of legal institutions) and Keith Hand, Resolving Constitutional Disputes in Contemporary China, 7 E. AsIA L. REv. 51, 53-54, n.5 (2012) (citing similar laments by journalist Evan Osnos, human rights advocate Joshua Rosensweig, and law professors/rights lawyers Jiang Ping, Teng Biao, and Fu Hualing). 
and discretion afforded administrative actors in China, and the relationship of those institutions to law and legal institutions.

A slightly more helpful, if still very partial, answer may be derived from Ben Liebman's work on contemporary China's "legal populism." ${ }^{109}$ Liebman discusses how judicial institutions in China can and do submit to populist pressure, in ways which are sometimes directly contrary to substantive law or promised legal procedure. In the present case, my focus is primarily on a different kind of state actor, an administrative agency with enforcement powers acting in a highly technical and often opaque area unlikely to attract popular interest. Still, the institutional receptivity to populist pressure may explain how the CSRC (and the Procuratorate in criminal enforcement) feels emboldened to act lawlessly in using "bad law" against "bad actors." Proceeding against identified securities fraudsters, the CSRC has-or can conjure-populist rage at its back, if not the law.

From the defendant side, these issues, and the paucity of legal challenges directed towards faulty norm-production and unlawful enforcement against China's most sophisticated and empowered civil actors, show us something equally disheartening: a continuing high tolerance for an administrative law establishment that does not act in conformity with law. This ultimately means a feeble constraint on state (and Communist Party) overreach.

What does this tell us about the "consumers" of rule of law in China today, and about their attitudes towards governance in accordance with law and robust legal accountability? As demonstrated in the broad and raucous clamor for a private right of action against issuers, underwriters, accountants, directors, officers and controlling shareholders in respect of securities issuance fraud and misrepresentation, ${ }^{\mathbf{1 1 0}}$ the domestic capital markets sector is hardly an area where retail and institutional market participants, or their legal counsel, have remained passive or ignorant of adequate remedies. Indeed, we see sustained recourse to legal institutions and explicitly legal challenges in the far more sensitive sphere of civil and political rights, in both the rural and urban settings. ${ }^{111}$

109. See Benjamin L. Liebman, A Populist Threat to China's Courts?, in CHInese Justice: Civil Dispute Resolution In Contemporary China 269-313 (Mary Gallagher \& Margaret Woo eds., 2011); and Benjamin L. Liebman, A Return to Populist Legality? Historical Legacies and Legal Reform, in MAO's Invisible HaNd 165-200 (Elizabeth Perry \& Sebastian Heilmann eds., 2011).

110. See Howson, supra note 85, at 303, 401-04; Donald C. Clarke \& Nicholas Calcina Howson, Pathway to Minority Shareholder Protection: Derivative Actions in the People's Republic of China, in The Derivative Action in Asia: A Comparative AND Functional APProach 258 (Daniel Puchniak et al. eds., 2012); Hui Huang, "Private Enforcement of Securities Law in China: A Ten Year Retrospective" (working paper (May 2012) on file with author).

111. See, e.g., Chen Guidi \& Wu Chuntao, Zhonguo Nongmin Diaocha Baogao [China Peasants Investigation RePort] (2004); Mary Gallagher, "Use the Law as Your Weapon!' Institutional Change and Legal Mobilization in China, in EnGAGING 
Yet, I would argue that in the world of securities trading the actors are different, with different kinds of leverage, and different expectations. Moreover, the legal challenges to the CSRC's rule making and enforcement practice are highly complex and technical. In the situation analyzed in this Article, there is only a single defendant (or a small group of defendants), usually actually guilty of trading on the basis of non-public, material, information, facing the much more powerful CSRC or People's Procuratorate. Defective enforcement against insider trading in China is therefore characterized by a basic power imbalance between the enforcement agency and insider trading defendants, an ex ante understanding of moral guilt in the minds of defendants, a post-investigatory period information asymmetry, the strong expectation of deserved fine or punishment, and decidedly "populist" pressure supporting enforcement against individuals caught manipulating the securities markets for private gain. In addition, as mentioned, the available legal challenges to the CSRC's 2007 Insider Trading Guidance Provisions and their enforcement are highly technical. Contrast the problem described here to the other situations in China where vigorous legal challenges to state action are made, such as eviction from land without legal basis, appropriate process, or compensation, or the inability to access counsel or to cross-examine witnesses in criminal proceedings. In these latter situations, the legal objection to enforcement is relatively clear cut and thus easily invoked by even minimally competent counsel. Is it reasonable to assume that insider trading defendants would think of (or retain lawyers who would counsel) a very sophisticated legal challenge to the insider trading enforcement regime itself, or the way it is applied by the agency directly charged with enforcement? Probably not. In the future, however, it is precisely this kind of sophisticated legal challenge to state power and enforcement, in any area, which will prove the effectiveness of external legal constraints generally and progress towards authentic "rule of law" in China.

\footnotetext{
Law In China: State, Society and Possibilities for Justice (Neil J. Diamant \& Kevin O'Brien eds., 2005); Keith Hand, Using Law for a Righteous Purpose: The Sun Zhigang Incident and Evolving Forms of Citizen Action in the People's Republic of China, 45 Colum. J. Trans. L. 114 (2006); Kevin O'brien \& Lianguian Li, Rightful Resistance in Rural China (2006); C.K. Lee, Against the Law: Labor Protests in China's Rustbelt and Sunbelt (2007); Fu Hualing \& Richard Cullen, Weiquan (Rights Protection) Lawyering in an Authoritarian State: Building a Culture of Public Interest Lawyering, 59 CHINA J. 111 (2008); Xiao Han, Qunti Peichang: Quanyi Yü Jiuan [Mass Compensation: Rights and Stability], CAIJING, Oct. 13, 2008, at 152-153; and a great deal of other scholarship, journalism and advocacy charting the rise of (legal) rights consciousness and demands on legal institutions in the PRC, and the various forms of state and Communist Party pushback.
} 


\section{Appendix I-Summaries of Selected CSRC Insider Trading ENFORCEMENT ACTIONS}

\section{Lin Shiquan-Trading in Shares of Yantai Xinchao Enterprise Co., Ltd. (June 29, 2011) ${ }^{112}$}

The controlling shareholders of Yantai Xinchao Enterprise Co., Ltd. (Yantai Xinchao) began negotiating a sale of equity in Yantai Xinchao on March 22, 2011, and Yantai Xinchao made public disclosure of a possible change of control on May 15, 2011. Defendant Lin Shiquan learned about the negotiations for a change of control transaction on March 24, 2011 (the decision does not indicate how, or why, Lin learns of the possible transaction, and whether he is a statutory PWKII under Article 74 of the 2006 PRC Securities Law or is proven to have misappropriated information under Articles 73 and 76), and on March 25, 2011 purchased 400,000 shares of Yantai Xinchao at renminbi (RMB) 6.69-6.72 yuan per share. After public disclosure of the possible change of control on May 15, 2011, on May 24, 2011, Lin sold his 400,000 shares for RMB 6.85-6.91 yuan per share, for total proceeds of RMB 2.75 million yuan and a trading profit of RMB 55,570 yuan. The CSRC levies a penalty equal to the trading profit, confirming that Lin is being penalized for insider trading pursuant to Article 202 of the 2006 PRC Securities Law. Of interest in the case is the care with which the CSRC identifies the news of a possible change of control as a "major event" for the issuer, qualifying it as "inside information" pursuant to Article 75 of the 2006 PRC Securities Law. Importantly, however, the CSRC does not indicate how Lin qualifies as one of the Article 74-enumerated persons, stating in conclusory terms that on March 24, 2011 he became a "person with knowledge of inside information." He is not identified as an officer or shareholder of the selling controlling shareholder of the issuer, although he is identified as the top executive of another entity which may be a shareholder of the issuer holding more than five percent of the issuer per Article 74(ii). This crucial fact basis is not set out in the decision.

\section{Liu Yang-Trading in Shares of ST Zhongwu Co., Ltd.} $\underline{\text { (June 14, 2011) }}^{113}$

Liu Yang is a senior officer of Hunan Construction Engineering Group Holdings Company (Hunan Construction Engineering) which begins considering a listing by reverse merger into several already-

112. Zhongguo Zhengjiannhui Xingzheng Chufa Juedingshu (Lin Shiquan) [CSRC Administrative Punishment Decision (Lin Shiquan)] (2011) No. 26, issued June 29, 2011, available at http://www.csrc.gov.cn/pub/zjhpublic/G00306212/201108/t201108 02_198433.htm.

113. Zhongguo Zhengiianhui Xingzheng Chufa Juedingshu (Liu Yang) [CSRC Administrative Punishment Decision (Liu Yang)] (2011) No. 24, issued June 14, 2011, 
listed entities, including ST Zhongwu Co., Ltd. (Zhongwu). Liu Yang is one of the executives in charge of the proposed transaction, and specifically liaison with the Hunan State-owned Assets Bureau (the governing department for each of the reverse merger candidates), which department confirms directly to Liu Yang on August 21, 2009 that only Zhongwu is available for the transaction. On September 29, 2009, the Hunan State-owned Assets Bureau formally approves Zhongwu as the target, and on the same day the chairman of Zhongwu's largest shareholder agrees to the same plan with the chairman of Zhongwu. On October 20, 2009, Zhongwu issues a "major event" report to the market, describing the proposed transaction, whereupon its shares cease trading. The CSRC determines that the period between September 29 (government approval of the transaction) and October 20, 2009 (public disclosure of the transaction) is the time period when there is inside information not yet made public, and further demonstrates that Liu Yang, through a friend named Xie and his or her securities account, spent RMB 4,181,624.91 yuan to purchase 421,000 shares of Zhongwu between October 15 and 19, 2009. In the event, Liu Yang fails to make serious gains on Zhongwu stock because on November 16, 2009 Zhongwu issues another "major event" report, detailing the breakdown of the takeover plan, on which day its shares commenced trading again. On the day of the second announcement and the re-start of trading, Zhongwu shares decline $1.61 \%$ to RMB 10.38 yuan per share. Liu Yang sells his shares in Zhongwu on November 18, 2009, showing a small net profit of RMB $11,212.83$ yuan. Most interesting in the decision, and indicative of how liberally the CSRC applies Article 74 of the 2006 PRC Securities Law, is that Liu Yang is pronounced "a person with knowledge of inside information" simply because he "participated in ... [the reverse merger] related affairs." This is not the same thing as what is provided for under Article 74(iv) ("persons who are able to obtain relevant inside information concerning the company by virtue of the position they hold in the company"), which is unavailable precisely because Liu Yang comes into possession of important information about a company (Zhongwu) different from the one he is employed by (Hunan Construction Engineering). The CSRC makes no effort to base Liu Yang's liability in the misappropriation prong of the statute.

available at http://www.csrc.gov.cn/pub/zjhpublic/G00306212/201107/t20110718_1976 05.htm. 
Jia Huazhang and Liu Rong-Trading in Shares of Xintai Science and Technology Co., Ltd. (December 21, 2010) ${ }^{114}$

This decision addresses a somewhat conventional husband and wife insider trading scheme: On April 26, 2006, the second largest shareholder of listed company Xintai Science and Technology Co., Ltd. (Xintai) agrees to sell its $26.81 \%$ stake in Xintai, which agreement is reported publicly on April 29, 2006. Ms. Liu Rong, the wife of Jia Huazhang, purchases shares of Xintai after the agreement is struck and before it is disclosed to the market, on April 26 (2,300 shares) and April $27(5,000)$ shares. Liu Rong later sells 300 shares in Xintai, on May 24, 2006, gaining a net profit of RMB 5,039 yuan. In terms of application of the law, the decision is problematic in several ways. First, the husband Jia Huazheng is simply declared to be a "person with knowledge of inside information" without tying his status to the enumerated persons under Article 74 of the 2006 PRC Securities Law. Nor is he independently identified as a misappropriater under Article 76. He may be a "tipper" of inside information, but as he is neither a "person with knowledge of inside information" nor a misappropriator, he is not subject to the tipping prohibition under Article 76. Thus, as a person who has merely come into possession of inside information, it is unclear how he is an insider trading defendant under the statute. Second, Jia's wife, Liu Rong, is a "tippee" of inside information, and again there is no tie up between her possession of the information and any kind of misappropriation. So, she is not an appropriate defendant under Article 76 of the PRC 2006 Securities Law.

\section{Zhang Xiaojian-Trading in Shares of Guilin Jiqi Pharmaceuticals Enterprise Co., Ltd. (December 6, 2010) ${ }^{115}$}

In this decision, Zhang Xiaojian is the vice-president of a PRC securities firm which agrees to advise on the reorganization of a troubled listed company, Guilin Jiqi Pharmaceuticals Enterprise Co., Ltd. (Jiqi). Discussions on the transaction are initiated and settled between the defendant's securities firm and Jiqi during the week of November 7-14, 2006 in Beijing, with the parties agreeing that the deal will involve a significant change in the capital structure of Jiqi. On December 13, 2006, public disclosure of the transaction and the change in capital structure was effected. In the period after the nego-

114. Zhongguo Zhengiianhui Xingzheng Chufa Juedingshu (Jia Huazhang Liu Rong) [CSRC Administrative Punishment Decision (Jia Huazhang and Liu Rong)] (2010) No. 53, issued Dec. 21, 2010, available at http://www.csrc.gov.cn/pub/zjhpublic/ G00306212/201103/t20110302_192554.htm.

115. Zhongguo Zhengianhui Xingzheng Chufa Juedingshu (Zhang Xiaojian) [CSRC Administrative Punishment Decision (Zhang Xiaojian)] (2010) No. 44, issued Dec. 6, 2010, available at $\mathrm{http} / / / \mathrm{www} . c s r c . g o v . c n / p u b /$ jh hpublic/G00306212/201102/t2 0110223_192241.htm. 
tiations and before public disclosure, Zhang Xiaojian used his younger brother's securities trading account at the same securities firm to purchase shares of Jiqi, on November 14 (493,000 shares) and again on November 22 (32,000 shares). There is no indication in the decision that Zhang Xiaojian sold the shares purchased during the price sensitive period, or profited from his purchase based on inside information. As in the Liu Yang CSRC decision above, Zhang Xiaojian is identified as a "person with knowledge of inside information" simply because he met with the chairman of his own securities firm in Beijing on November 13, 2006 and thereafter "participated" in implementation of the transaction regarding "Jiqi." This style of identification by the CSRC is odd, because Zhang Xiaojian might fit rather comfortably within the terms of the 2006 PRC Securities Law Article 74(vi) ("personnel of securities service institutions"). It is yet another example of how the CSRC will rather liberally enforce against people trading on inside information simply by virtue of their access to such inside information, regardless of whether or not they fit neatly into the enumerated class of defendants under Article 74. 


\section{Appendix II-Selected Statutory Provisions}

\section{PRC Securities Law}

Article 73. It is prohibited for those with knowledge of securities trading [related] inside information or those who have illegally procured inside information to use inside information in undertaking securities trading activities.

Article 74. Persons with knowledge of securities trading [related] inside information include:

(i) directors, supervisory board members, and senior managers of the issuer;

(ii) $5 \%$ or more shareholders of the company and its/their directors, supervisory board members and senior managers, and the actual controlling shareholders of the company and its/their directors, supervisory board members and senior managers;

(iii) directors, supervisory board members and senior managers of companies controlled by the issuer; 116

(iv) people whose executive or staff position in the company provides access to inside information;

(v) Securities Regulatory Organ [CSRC] staff and others who pursuant to their legally stipulated duties administer or regulate securities issuance and trading;

(vi) relevant securities sponsors, underwriters, securities exchange personnel, securities registration and settlement personnel, and securities service institution personnel; and

(vii) other persons stipulated in regulation by the State Council Securities Regulatory Organ [the CSRC].

Article 75. Inside information means non-public information relevant to a company's business or financial affairs or which may have a major effect on the market price of that company's securities in the course of securities trading activities. The following information all constitutes inside information: . . .(viii) other important information recognized and confirmed by the State Council Securities Regulatory Organ [the CSRC] to have a significant effect on the trading price of securities.

Article 76. Those with knowledge of inside information related to securities trading and those who have illegally procured inside information may not, prior to public disclosure of the inside information, purchase or sell that company's securities, or disclose such

116. Appropriately adjusted in Article 6(2)(ii) of the 2007 Insider Trading Guidance Provisions to mean: "the controlling shareholders of the issuer or listed company, other companies controlled by the actual control party, and their directors, supervisory board members and senior management." 
information, or suggest that others purchase or sell such securities -...

\section{Insider Trading Guidance Provisions}

Article 12. Securities trading activity that conforms to the following conditions shall constitute insider trading: (1) the person undertaking the behavior is an insider; (2) the information involved is inside information; and (3) the subject person buys or sells related securities during the price sensitive period of the inside information, or suggests that other persons buy or sell related securities, or [publicly] reveals the [inside] information. ${ }^{117}$

117. Each of "insider," "inside information," and "price sensitive period" is defined under the 2007 Insider Trading Guidance Provisions, only one of which ("inside information") is defined under the 2006 PRC Securities Law. As noted in the text of this Article, the expanded definition of PWKII under the 2007 Insider Trading Guidance Provisions is folded back into the newly-created and much expanded term "insider." 